\title{
Chemical Composition, Antioxidant, Anti-Tyrosinase, Anti-Cholinesterase and Cytotoxic Activities of Essential Oils of Six Algerian Plants
}

\author{
Kadour Cheraif ${ }^{1}$, Boulanouar Bakchiche ${ }^{1}{ }^{\mathbb{D}}$, Abdelaziz Gherib ${ }^{1}$, Sanaa K. Bardaweel ${ }^{2} \mathbb{D}$, \\ Melek Çol Ayvaz ${ }^{3}$, Guido Flamini ${ }^{4, *(D)}$, Roberta Ascrizzi ${ }^{4}$ (D) and Mosad A. Ghareeb ${ }^{5}$ (D) \\ 1 Laboratory of Process Engineering, Faculty of Technology, Amar Telidji University, Laghouat 03000, Algeria; \\ cheraifkadour@yahoo.fr (K.C.); b.bakchiche@lagh-univ.dz (B.B.); a.gherib@lagh-univ.dz (A.G.) \\ 2 Department of Pharmaceutical Sciences, School of Pharmacy, University of Jordan, Amman 11942, Jordan; \\ s.bardaweel@ju.edu.jo \\ 3 Department of Chemistry, Faculty of Science and Arts, Ordu University, 52200 Ordu, Turkey; \\ melekcol@hotmail.com \\ 4 Dipartimento di Farmacia, Università di Pisa, Via Boanno 6, 56126 Pisa, Italy; roberta.ascrizzi@gmail.com \\ 5 Medicinal Chemistry Department, Theodor Bilharz Research Institute, Kornaish El-Nile, Warrak El-Hadar, \\ Imbaba (P.O. 30), Giza 12411, Egypt; m.ghareeb@tbri.gov.eg \\ * Correspondence: guido.flamini@unipi.it
}

Academic Editors: Gianni Sacchetti and Vincenzo De Feo

Received: 9 March 2020; Accepted: 7 April 2020; Published: 8 April 2020

check for updates

\begin{abstract}
In this study, the essential oils (EOs) of six Algerian plants (Artemisia campestris L., Artemisia herba-alba Asso, Juniperus phoenicea L., Juniperus oxycedrus L., Mentha pulegium L. and Lavandula officinalis Chaix) were obtained by hydrodistillation, and their compositions determined by GC-MS and GC-FID. The antioxidant activity of the EOS was evaluated via 2,2'-diphenyl-1-picrylhydrazyl (DPPH), ferric-reducing/antioxidant power (FRAP) and 2,2'-azino-bis(3-ethylbenzothiazoline-6-sulphonic acid (ABTS) assays. Moreover, their cytotoxic effect was evaluated-as well as their tyrosinase, acetyl- and butyryl-cholinesterase (AChE and BuChE) inhibitory activities. The chemical analyses detected 44, 45, 51, 53, 26 and 40 compounds in EOs of A. campestris, A. herba-alba, J. phoenicea, J. oxycedrus, M. pulegium and L. officinalis, respectively. A. campestris $\mathrm{EO}$ was mainly composed of $\beta$-pinene $(20.7 \%)$, while $A$. herba-alba $\mathrm{EO}$ contained davanone $\mathrm{D}(49.5 \%)$ as the main component. $\alpha$-Pinene $(41.8 \%)$ was detected as the major constituent in both J. phoenicea $(41.8 \%)$ and J. oxycedrus $(37.8 \%)$ EOs. M. pulegium EO was characterized by pulegone as the most abundant $(76.9 \%)$ compound, while linalool $(35.8 \%)$ was detected as a major constituent in L. officinalis EO. The antioxidant power evaluation revealed IC50 values ranging from 2.61 to $91.25 \mathrm{mg} / \mathrm{mL}$ for DPPH scavenging activity, while the FRAP values ranged from $0.97-8.17 \mu \mathrm{mol}$ Trolox equivalents (TX)/g sample. In the ABTS assay, the values ranged from 7.01 to $2.40 \mu \mathrm{mol} T X / \mathrm{g}$ sample. In the presence of $1 \mathrm{mg} / \mathrm{mL}$ of the samples, tyrosinase inhibition rates ranged from $11.35 \%$ to $39.65 \%$, AChE inhibition rates ranged from $40.57 \%$ to $73.60 \%$ and $\mathrm{BuChE}$ inhibition rates ranged from $6.47 \%$ to $72.03 \%$. A significant cytotoxic effect was found for A. herba-alba EO. The obtained results support some of the traditional uses of these species in food preservation and for protection against several diseases.
\end{abstract}

Keywords: Artemisia campestris; Artemisia herba-alba; Juniperus phoenicea; Juniperus oxycedrus; Mentha pulegium; Lavandula officinalis; essential oils; GC/MS; antioxidant activity; acetylcholinesterase; butyrylcholinesterase; tyrosinase 


\section{Introduction}

Essential oils (EOs) are complex mixtures of volatile compounds biosynthesized by plants in response to environmental and ecological needs [1]. In traditional medicines, EOs have been used since ancient times in the treatment of various ailments and health disorders. They have been extensively investigated for their important biologic applications, such as antimicrobial [2], antioxidant [3], antiproliferative [4], antimalarial and trypanocidal [5] and antitumoral [6]. Among the most useful EO applications, their use as antioxidant agents is highly investigated, since the phenomenon known as oxidative stress is the root of several health problems, like inflammations, cancer, neurodegeneration and cardiovascular diseases. The over-production of free radicals, highly energetic molecules containing odd electrons, mostly represented by reactive oxygen species (ROS), is involved in this phenomenon; as naturally occurring antioxidant agents, EOs may attenuate this damage through their radical scavenging effect [7-11]. Among the neurodegenerative diseases sustained by inflammation, Alzheimer's disease (AD) represents the predominant reason of dementia in old people. Memory and language impairment, cognitive dysfunction and behavioral disturbances are common symptoms of AD. Moreover, the reduction in acetylcholine $(\mathrm{ACh})$ levels in the hippocampus and cortex of the brain is a common biochemical change detected in AD patients. Consequently, the starting point for the treatment of AD is the inhibition of acetylcholinesterase (AChE) and butyrylcholinesterase (BChE), both responsible for the hydrolysis of ACh in the cholinergic synapse [12-17].

In this framework, the study of widely distributed species rich in EOs as sources of naturally occurring bioactive agents is of great importance, in order to exploit their large bioavailability. In the present work, attention was focused on six species belonging to the Algerian flora: Artemisia campestris L., Artemisia herba-alba Asso, Juniperus phoenicea L., Juniperus oxycedrus L., Mentha pulegium L. and Lavandula officinalis Chaix. An overview of the popular names, traditional medicinal uses and main EO compounds of the Algerian species selected for the present study is reported in Table 1.

Table 1. Bibliographical overview of the popular names, traditional medicinal uses and main essential oils (EO) compounds of the Algerian species selected for the present study.

\begin{tabular}{|c|c|c|c|c|}
\hline Family/Species & Local Name & Medicinal Uses in Algeria & $\begin{array}{l}\text { Major Compounds of } \\
\text { the Selected Species }\end{array}$ & References \\
\hline \multicolumn{5}{|c|}{ Asteraceae } \\
\hline A. campestris & Dgouft & Antidiabetic, antihypertensive & $\begin{array}{c}\beta \text {-pinene }(25 \%), \text { sabinene } \\
(17 \%), \alpha \text {-pinene }(9.9 \%) \\
\text { limonene }(6.6 \%)\end{array}$ & {$[18,19]$} \\
\hline A. herba-alba & Chih & $\begin{array}{l}\text { Antidiabetic, antispasmodic, } \\
\text { carminative, anti-eczema }\end{array}$ & $\begin{array}{l}\alpha \text {-thujone }(28.1 \%), \\
\text { camphor }(22.8 \%), \\
1,8 \text {-cineole }(8.2 \%)\end{array}$ & [19-21] \\
\hline \multicolumn{5}{|c|}{ Cupressaceae } \\
\hline J. phoenicea & Aar-aar & $\begin{array}{l}\text { Antidiarrheal, anti-rheumatic, } \\
\text { antidiabetic, diuretic }\end{array}$ & $\begin{array}{l}\alpha \text {-pinene }(75.8 \%), \\
\delta \text {-3-carene }(3.4 \%)\end{array}$ & {$[18,22]$} \\
\hline J. oxycedrus & Taga & $\begin{array}{l}\text { Anti-inflammatory, anti-eye } \\
\text { infections }\end{array}$ & $\begin{array}{l}\text { trans-pinocarveol }(7 \%) \\
\text { cis-verbenol }(6.3 \%) \\
\text { manoyl oxide }(6 \%)\end{array}$ & {$[19,23]$} \\
\hline \multicolumn{5}{|c|}{ Lamiaceae } \\
\hline M. pulegium & Feliou & Antihypertensive,antispasmodic & $\begin{array}{c}\text { pulegone }(70.66 \%) \\
\text { neo-menthol }(11.21 \%), \\
\text { menthone }(2.63 \%)\end{array}$ & {$[19,20,24]$} \\
\hline L. officinalis & Khozama & $\begin{array}{l}\text { antispasmodic, anti-influenza, } \\
\text { treatments of abdominal pain }\end{array}$ & $\begin{array}{c}\text { linalyl acetate (32.98), } \\
\text { linalool (28.92\%), } \\
\text { lavandulyl acetate (4.52) }\end{array}$ & {$[20,25]$} \\
\hline
\end{tabular}


The genus Juniperus (Cupressaceae) comprises nearly 75 species, widely distributed in the Northern hemisphere, especially in Tunisia, Algeria and Morocco. Numerous studies reported the chemical composition and biologic activities of the EOs from different species of this genus [26-29]. Juniperus oxycedrus L. is shrub or small tree, native to the Mediterranean region; it has been used throughout history for several medical applications [29,30]. Juniperus phoenicea is an evergreen tree native to North Africa: traditionally, this plant was used for the treatment of hypoglycemia [31], diarrhea, rheumatism [32] and diabetes [32,33]. The genus Artemisia (Asteraceae) contains approximately 400 species, widely distributed in the Mediterranean region, Northern Africa, Western Asia, Southwestern Europe and Arabian Peninsula [34]. Artemisia herba-alba is a greenish-silver perennial herb belonging to the Asteraceae family, with many popular names: in Algeria it is known as the white wormwood, in Arabic as "Chih", and in France as "Armoise blanche" [35-37]. In traditional medicine, the plant has been used to treat many ailments including colds, coughing, bronchitis, intestinal disturbances, diarrhea, neuralgias arterial hypertension and/or diabetes [38-40]. For A. herba-alba EO, numerous biologic and pharmacological properties are reported in the literature, such as antimicrobial, antioxidant, antidiabetic, antileishmanial, anthelmintic and antispasmodic [36,37,41-45]. Artemisia campestris L. is a perennial herb, usually known as field wormwood. The plant is widely spread in Asia, North America, Europe and North Africa [46]. For this species, several ethnopharmacological uses are reported, such as anti-diabetic, anti-inflammatory, antioxidant, antimicrobial and antipyretic [47,48]. Lavandula, of the Lamiaceae family, is an aromatic genus with about 39 species distributed worldwide, from the Mediterranean region, to tropical Africa and the South-East regions of India [49-51]. It was traditionally used as spasmolytic, carminative, stomachic and diuretic [50]. Leaf and flower parts of most Lavandula species are rich in essential oils [50,52,53]. Lavandula officinalis Chaix. is a multifunctional medicinal and aromatic plant native to Southern Europe and the Mediterranean region [54], widely used in both the pharmaceutical and fragrance industries. The genus Mentha belongs to the Lamiaceae family: it is broadly distributed worldwide [55], comprising about 19 species and 13 natural hybrids, basically perennial herbs, growing in Europe, Asia, Africa, Australia and North America [55,56]. In folk medicine, Mentha species have been used for treatment of various ailments including nausea, bronchitis, flatulence, anorexia, ulcerative colitis and liver complaints, due to their anti-inflammatory, carminative, antiemetic, diaphoretic, antispasmodic, analgesic, stimulant, emmenagogue and anticatarrhal activities [56-60].

Because of the diverse chemical and biologic profiles of the selected species, the present study aimed at investigating the chemical profile of the essential oils (EOs) from these six Algerian plants by GC-MS analysis. Finally, their antioxidant, anti-tyrosinase and cytotoxic activities were evaluated.

\section{Results}

\subsection{Chemical Characterization of the Essential Oils}

The complete compositions of the essential oils (EOs) hydrodistilled from the aerial parts of the six selected Algerian species are reported in Table 2. All the obtained chromatograms are reported in Figures 1-6. For each species, the hydrodistillation was performed in triplicate: the average yields $(w / w)$ of extraction were $0.52 \%, 0.54 \%, 0.4 \%, 0.19 \%, 0.91 \%$ and $2.80 \%$, respectively for Artemisia campestris, Artemisia herba-alba, Juniperus phoenicea, Juniperus oxycedrus, Mentha pulegium and Lavandula officinalis.

Forty-four compounds were identified in A. campestris EO, representing $99.1 \%$ of the total composition. Monoterpene hydrocarbons were the most prominent chemical class of compounds, accounting for up to $75.7 \%$ : among them, $\beta$-pinene $(20.7 \%)$, limonene $(11.3 \%), \gamma$-terpinene $(11.0 \%)$, $\alpha$-pinene $(9.2 \%)$, myrcene $(5.8 \%)$ and $p$-cymene $(5.1 \%)$ were the most abundant. Sesquiterpenes followed, with similar relative abundances in their hydrocarbon and oxygenated forms $(9.0 \%$ and $10.0 \%$, respectively), exhibiting germacrene $\mathrm{D}(4.9 \%)$ and $\beta$-eudesmol $(3.9 \%)$ as the most represented compounds of the two classes, respectively. 


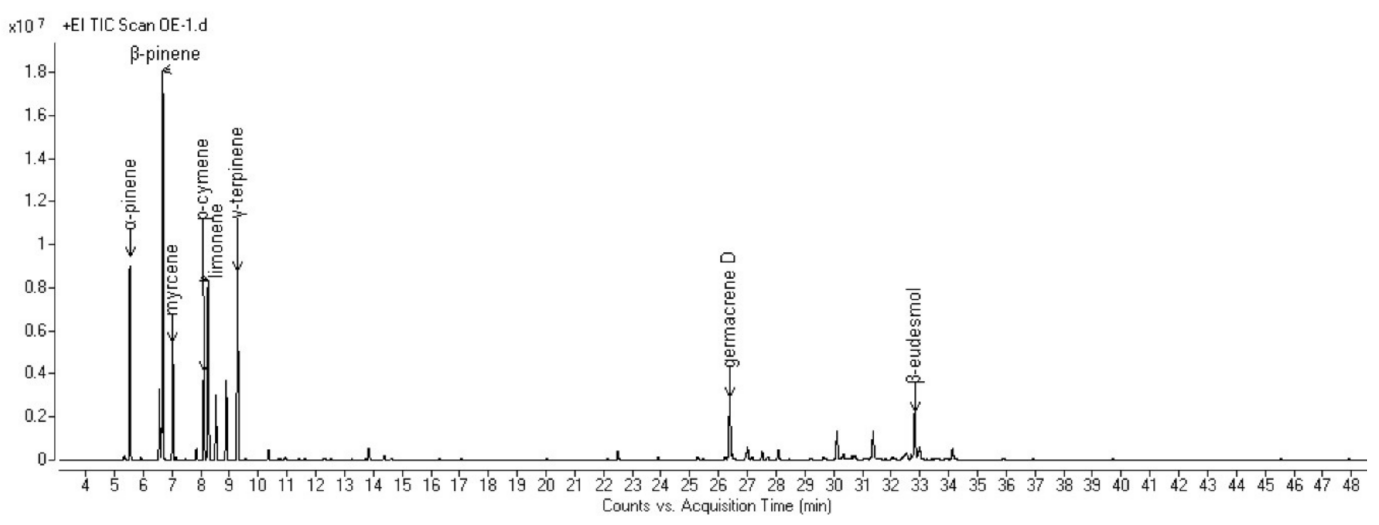

Figure 1. GC chromatogram of the EO hydrodistilled from the aerial parts of A. campestris L.

Forty-five compounds were identified in A. herba-alba EO, adding up to $92.2 \%$ of the total composition, constituted for more than $70 \%$ by oxygenated terpenes. A. herba-alba EO was composed for more than $50 \%$ by oxygenated sesquiterpenes, among which the most abundant was davanone $\mathrm{D}$ (49.5\%). Among the monoterpenoids, camphor (10.0\%) was the most represented.

In J. phoenicea EO, fifty-one compounds were identified, representing $97.5 \%$ of the composition. Terpene hydrocarbons were the most abundant compounds: monoterpene hydrocarbons, in particular, accounted for almost $60 \%$ of the total. Among them, the most abundant was $\alpha$-pinene, which represented over $40 \%$ of the composition, followed by $\delta$-3-carene $(8.4 \%)$. For the sesquiterpenes, trans-calamenene showed the highest relative abundance $(4.2 \%)$ within the hydrocarbons, while 1-epi-cubenol was the main (3.7\%) oxygenated one.

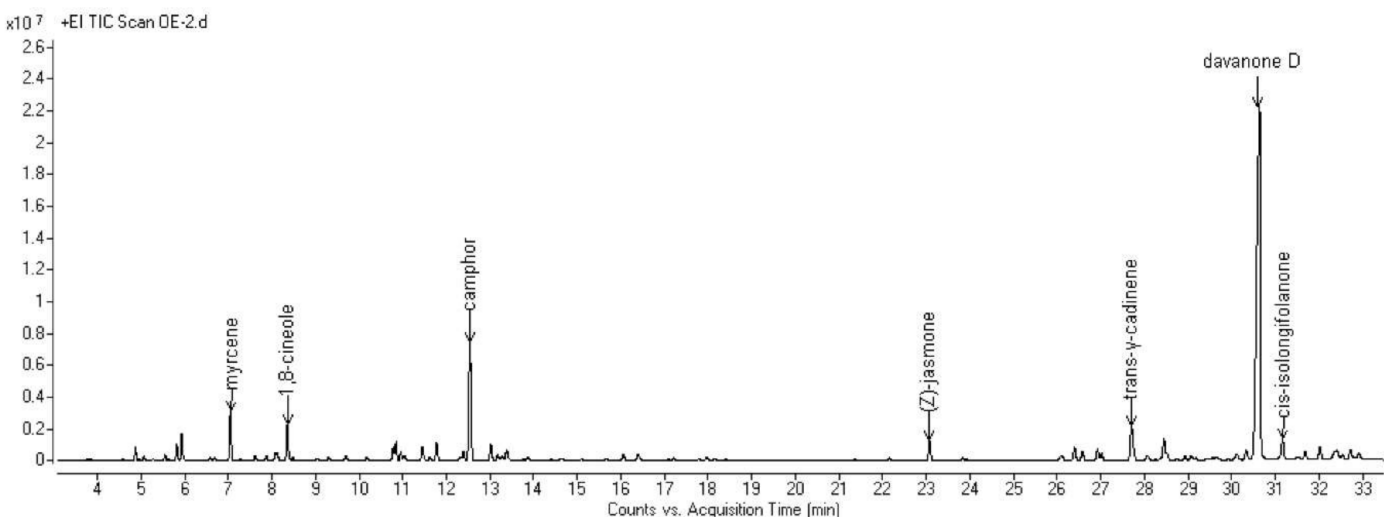

Figure 2. GC chromatogram of the EO hydrodistilled from the aerial parts of A. herba-alba Asso.

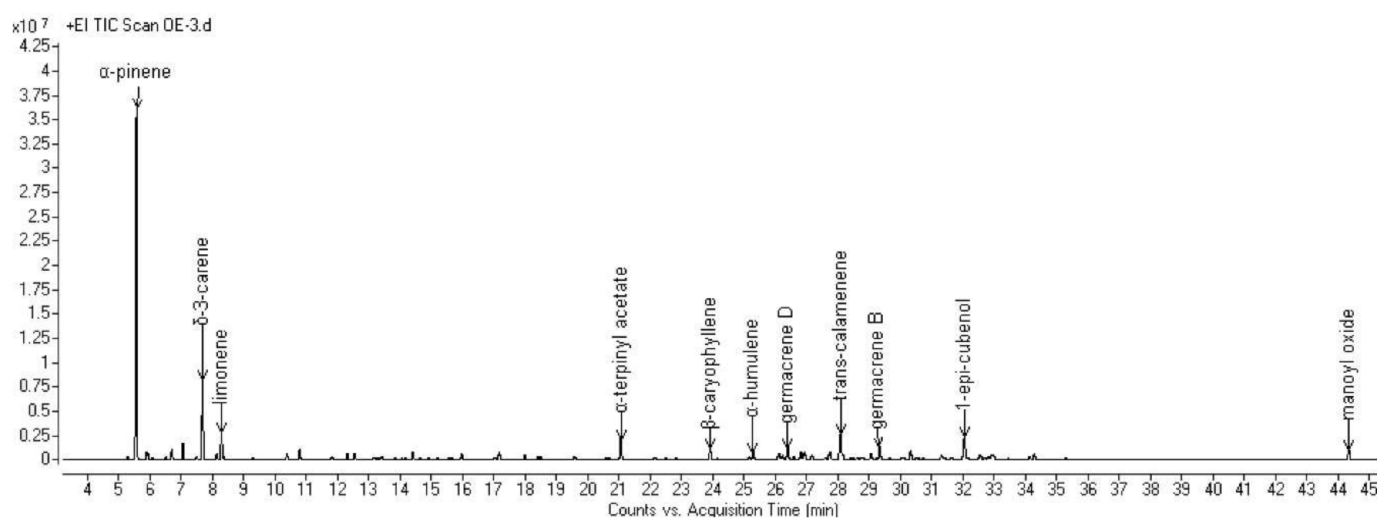

Figure 3. GC chromatogram of the EO hydrodistilled from the aerial parts of J. phoenicea L. 
Fifty-three compounds were detected in J. oxycedrus EO, representing $95.8 \%$ of the composition. Monoterpene hydrocarbons were the main chemical class (46.3\%), among which $\alpha$-pinene accounted for over $35 \%$, thus representing the most abundant compound in the composition. Oxygenated sesquiterpenes followed (21.4\%), with bulnesol as the most represented (7.2\%). Diterpenes were also relevantly represented: abietadiene showed a relative abundance over $8 \%$, while manoyl oxide was up to $5 \%$.

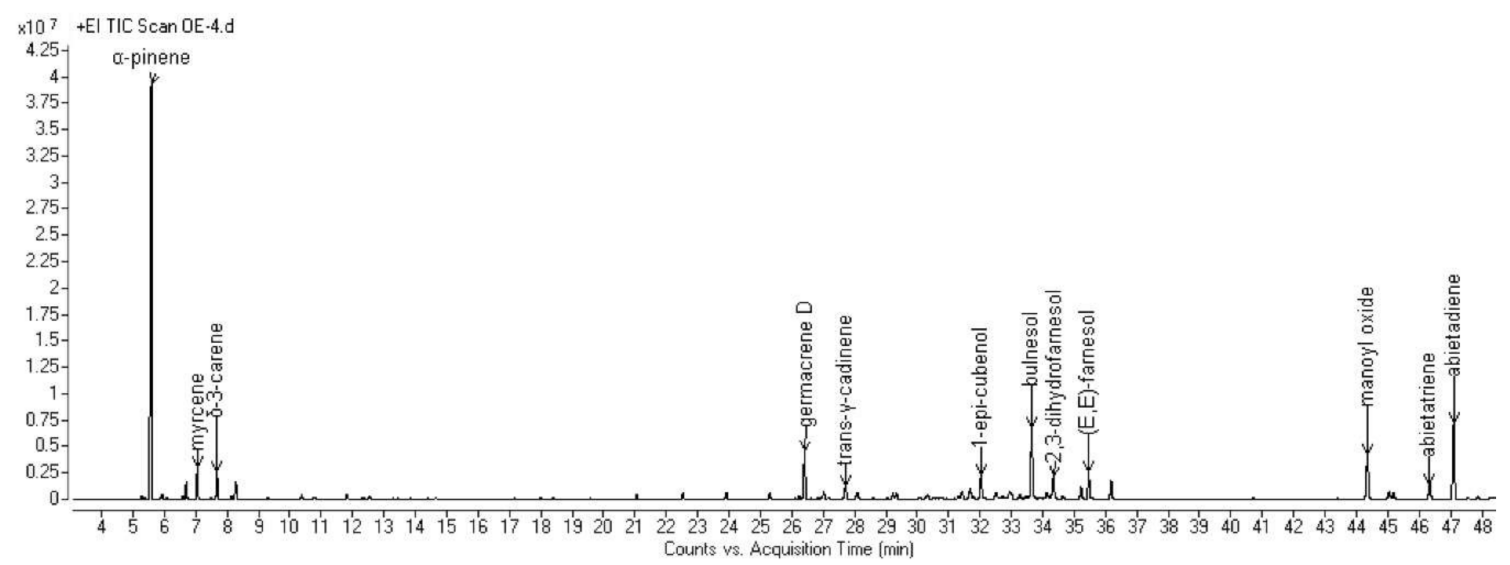

Figure 4. GC chromatogram of the EO hydrodistilled from the aerial parts of J. oxycedrus L.

M. pulegium EO contained twenty-six volatile constituents, representing $96.8 \%$ of the total. Its composition was dominated (over $90 \%$ ) by oxygenated monoterpenes: the plant, indeed, exhibited a pulegone chemotype [61], as this compound was the most abundant (76.9\%) in the EO, followed by piperitenone $(6.05 \%)$.

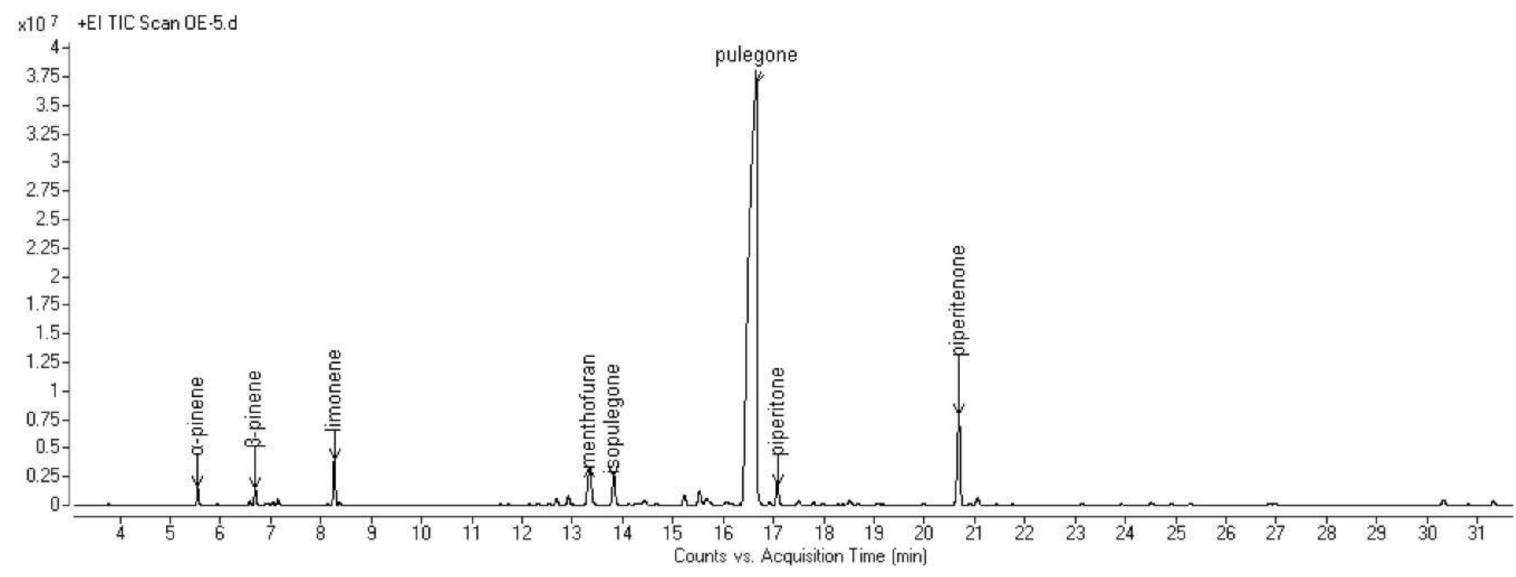

Figure 5. GC chromatogram of the EO hydrodistilled from the aerial parts of M. pulegium L.

Forty compounds were identified in L. officinalis EO, representing 98.5\% of the total. Almost $90 \%$ of its composition was constituted by oxygenated monoterpenes, of which linalool and linalyl acetate were the most abundant, as they accounted for up to $35.8 \%$ and $21.0 \%$, respectively. 


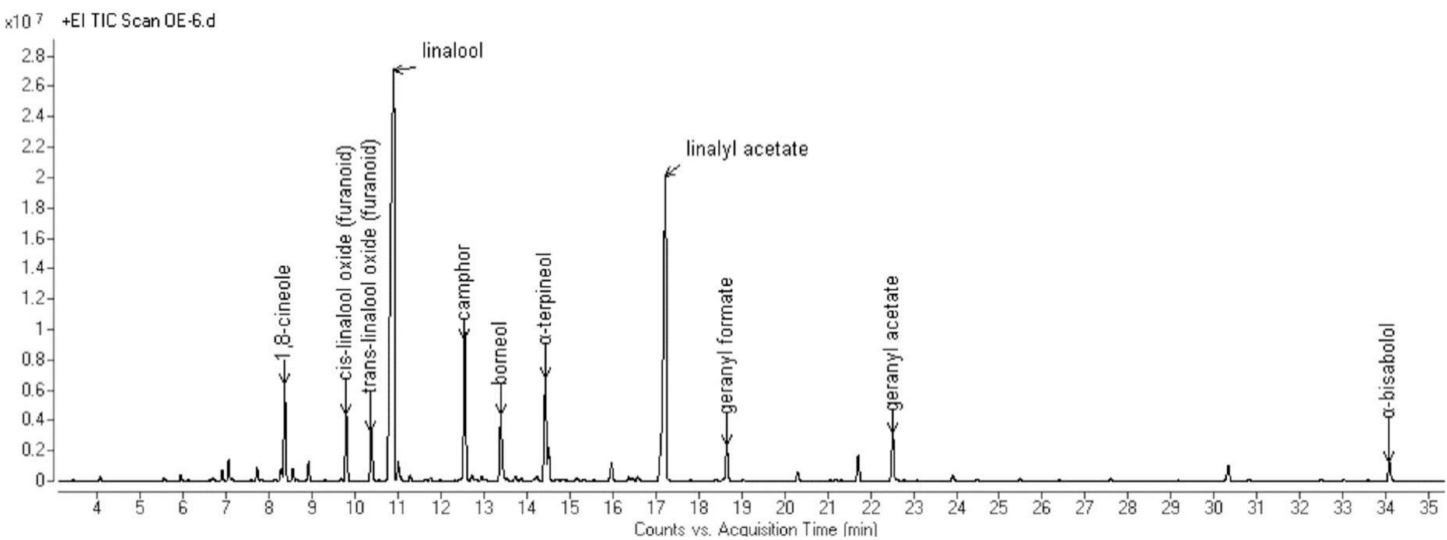

Figure 6. GC chromatogram of the EO hydrodistilled from the aerial parts of L. officinalis Chaix.

Table 2. Complete compositions of the essential oils hydrodistilled from the aerial parts of the six Algerian species selected in the present work.

\begin{tabular}{|c|c|c|c|c|c|c|c|}
\hline \multirow[t]{2}{*}{ Compounds } & \multirow[t]{2}{*}{ 1.r.i. ${ }^{a}$} & \multicolumn{6}{|c|}{ Relative Abundance (\%) } \\
\hline & & $\begin{array}{l}\text { Artemisia } \\
\text { campestris }\end{array}$ & $\begin{array}{l}\text { Artemisia } \\
\text { herba-alba }\end{array}$ & $\begin{array}{l}\text { Juniperus } \\
\text { phoenicea }\end{array}$ & $\begin{array}{l}\text { Juniperus } \\
\text { oxycedrus }\end{array}$ & $\begin{array}{l}\text { Mentha } \\
\text { pulegium }\end{array}$ & $\begin{array}{l}\text { Lavandula } \\
\text { officinalis }\end{array}$ \\
\hline 1-hexanol * & 871 & $-\mathrm{b}$ & 0.7 & - & - & - & 0.1 \\
\hline santolina triene & 911 & - & 0.2 & - & - & - & - \\
\hline $\begin{array}{l}\text { 2,5-diethenyl-2- } \\
\text { methyltetrahydrofuran }\end{array}$ & 913 & - & 0.3 & - & - & - & - \\
\hline tricyclene & 928 & - & - & 0.2 & 0.2 & - & - \\
\hline$\alpha$-thujene & 933 & 0.2 & - & - & 0.1 & - & - \\
\hline$\alpha$-pinene ${ }^{*}$ & 941 & 9.2 & 0.3 & 41.8 & 37.8 & 0.7 & 0.1 \\
\hline$\alpha$-fenchene & 954 & - & - & 0.7 & 0.1 & - & - \\
\hline camphene * & 955 & 0.1 & 1.7 & 0.5 & 0.3 & - & 0.2 \\
\hline 3-methylcyclohexanone * & 956 & - & - & - & - & 0.1 & - \\
\hline thuja-2,4(10)-diene & 959 & - & - & 0.2 & 0.1 & - & - \\
\hline sabinene * & 977 & 3.6 & 0.1 & - & 0.2 & 0.2 & - \\
\hline$\beta$-pinene * & 982 & 20.7 & 0.2 & 1.0 & 1.1 & 0.8 & 0.1 \\
\hline 3-octanone * & 988 & - & - & - & - & 0.1 & 0.4 \\
\hline myrcene * & 993 & 5.8 & 3.0 & 1.6 & 2.1 & 0.1 & 0.8 \\
\hline 3-octanol * & 994 & - & - & - & - & 0.2 & 0.2 \\
\hline$\alpha$-phellandrene * & 1006 & - & - & 0.3 & 0.1 & - & - \\
\hline 1-hexyl acetate * & 1010 & - & - & - & - & - & 0.5 \\
\hline 8-3-carene * & 1011 & - & - & 8.4 & 1.9 & - & - \\
\hline$\alpha$-terpinene ${ }^{*}$ & 1020 & 0.6 & 0.3 & - & - & - & - \\
\hline$p$-cymene ${ }^{*}$ & 1028 & 5.1 & 0.5 & 0.6 & 0.2 & 0.1 & - \\
\hline limonene * & 1032 & 11.3 & - & 3.3 & 1.6 & 2.1 & - \\
\hline 1,8-cineole * & 1034 & - & 2.6 & 0.3 & - & 0.2 & 4.0 \\
\hline santolina alcohol & 1039 & - & 0.2 & - & - & - & - \\
\hline (Z)- $\beta$-ocimene & 1042 & 3.3 & - & - & - & - & 0.5 \\
\hline (E)- $\beta$-ocimene & 1052 & 4.2 & - & - & - & - & 0.7 \\
\hline$\gamma$-terpinene ${ }^{*}$ & 1063 & 11.0 & 0.2 & 0.2 & 0.1 & - & - \\
\hline 1-octanol * & 1071 & - & - & - & - & - & 0.1 \\
\hline $\begin{array}{l}\text { cis-linalool oxide } \\
\text { (furanoid) }\end{array}$ & 1076 & - & - & - & - & - & 2.9 \\
\hline artemisia alcohol & 1084 & - & 0.2 & - & - & - & - \\
\hline terpinolene * & 1090 & 0.6 & - & 0.8 & 0.4 & - & - \\
\hline $\begin{array}{l}\text { trans-linalool oxide } \\
\text { (furanoid) }\end{array}$ & 1091 & - & - & - & - & - & 2.4 \\
\hline linalool * & 1101 & - & 0.9 & 1.2 & 0.2 & - & 35.8 \\
\hline nonanal * & 1102 & 0.1 & - & - & - & - & - \\
\hline$\alpha$-thujone ${ }^{*}$ & 1104 & - & 0.3 & - & - & - & - \\
\hline 1-octen-3-yl acetate * & 1110 & - & - & - & - & - & 0.2 \\
\hline $\begin{array}{l}\text { cis-linalool oxide } \\
\text { (pyranoid) }\end{array}$ & 1117 & - & 1.1 & - & - & - & - \\
\hline cis-p-menth-2-en-1-ol & 1123 & - & 0.2 & - & - & - & - \\
\hline
\end{tabular}


Table 2. Cont.

\begin{tabular}{|c|c|c|c|c|c|c|c|}
\hline \multirow[t]{2}{*}{ Compounds } & \multirow[t]{2}{*}{ 1.r.i. ${ }^{a}$} & \multicolumn{6}{|c|}{ Relative Abundance (\%) } \\
\hline & & $\begin{array}{l}\text { Artemisia } \\
\text { campestris }\end{array}$ & $\begin{array}{l}\text { Artemisia } \\
\text { herba-alba }\end{array}$ & $\begin{array}{l}\text { Juniperus } \\
\text { phoenicea }\end{array}$ & $\begin{array}{l}\text { Juniperus } \\
\text { oxycedrus }\end{array}$ & $\begin{array}{l}\text { Mentha } \\
\text { pulegium }\end{array}$ & $\begin{array}{l}\text { Lavandula } \\
\text { officinalis }\end{array}$ \\
\hline 3-octyl acetate * & 1124 & - & - & - & - & - & 0.1 \\
\hline chrysanthenone & 1126 & - & 1.4 & - & - & - & - \\
\hline$\alpha$-campholenal & 1127 & - & - & 0.3 & 0.4 & - & - \\
\hline trans-pinocarveol & 1141 & 0.1 & 0.3 & 0.7 & 0.1 & - & - \\
\hline cis-verbenol * & 1142 & - & - & - & 0.1 & - & - \\
\hline trans-verbenol & 1143 & - & - & - & 0.3 & - & - \\
\hline camphor * & 1144 & - & 10.0 & 0.8 & - & - & 7.2 \\
\hline hexyl isobutyrate * & 1151 & - & - & - & - & - & 0.2 \\
\hline menthone ${ }^{*}$ & 1154 & - & - & - & - & 0.4 & - \\
\hline nerol oxide & 1155 & - & - & - & - & - & 0.2 \\
\hline$\beta$-pinene oxide & 1157 & - & 1.2 & - & - & - & - \\
\hline trans-pinocamphone & 1162 & - & - & 0.3 & - & - & - \\
\hline pinocarvone & 1164 & - & 0.3 & - & - & - & - \\
\hline menthofuran * & 1165 & - & - & - & - & 3.3 & - \\
\hline borneol $^{*}$ & 1168 & - & 1.0 & - & - & - & 3.6 \\
\hline $\begin{array}{l}\text { cis-linalool oxide } \\
\text { (pyranoid) }\end{array}$ & 1173 & - & - & - & - & - & 0.2 \\
\hline isopulegone & 1174 & - & - & - & - & 1.9 & - \\
\hline $\begin{array}{l}\text { trans-linalool oxide } \\
\text { (pyranoid) }\end{array}$ & 1177 & - & - & - & - & - & 0.2 \\
\hline 4-terpineol * & 1179 & 0.7 & 0.3 & - & - & - & 0.1 \\
\hline cryptone & 1185 & - & - & - & - & - & 0.2 \\
\hline$\alpha$-terpineol ${ }^{*}$ & 1191 & 0.3 & - & 1.0 & 0.1 & 0.3 & 5.2 \\
\hline hexyl butyrate * & 1192 & - & - & - & - & - & 1.5 \\
\hline myrtenol * & 1193 & 0.1 & 0.2 & - & 0.1 & - & - \\
\hline verbenone * & 1205 & - & - & - & - & 0.6 & - \\
\hline 8,9-dehydrothymol & 1222 & - & - & - & - & 0.5 & - \\
\hline citronellol * & 1229 & - & - & 0.7 & - & - & - \\
\hline nerol * & 1230 & - & - & - & - & - & 1.0 \\
\hline nordavanone & 1231 & - & 0.5 & - & - & - & - \\
\hline hexyl 2-methylbutyrate * & 1236 & - & - & - & - & - & 0.2 \\
\hline (Z)-3-hexenyl isovalerate & 1239 & 0.1 & - & - & - & - & - \\
\hline pulegone ${ }^{*}$ & 1240 & - & - & - & - & 76.9 & - \\
\hline cumin aldehyde * & 1241 & - & - & - & - & - & 0.2 \\
\hline piperitone * & 1254 & - & - & - & - & 1.3 & - \\
\hline lepalone & 1258 & - & 0.2 & - & - & - & - \\
\hline linalyl acetate ${ }^{*}$ & 1259 & - & - & 0.9 & - & - & 21.0 \\
\hline isopiperitone & 1271 & - & - & - & - & 0.1 & - \\
\hline lepalol & 1279 & - & 0.3 & - & - & - & - \\
\hline bornyl acetate * & 1286 & - & 0.1 & 0.4 & 0.1 & - & - \\
\hline $\begin{array}{l}\text { trans-linalool oxyde } \\
\text { acetate (pyranoid) }\end{array}$ & 1287 & - & - & 0.2 & - & - & - \\
\hline geranyl formate* & 1297 & - & - & - & - & - & 1.8 \\
\hline carvacrol ${ }^{*}$ & 1298 & - & - & - & - & 0.1 & - \\
\hline$(E, E)$-2,4-decadien-1-ol & 1311 & - & - & 0.5 & - & - & - \\
\hline hexyl tiglate * & 1332 & - & - & - & - & - & 0.4 \\
\hline piperitenone & 1342 & - & - & - & - & 6.0 & - \\
\hline$\alpha$-terpinyl acetate ${ }^{*}$ & 1352 & - & - & 2.7 & 0.4 & - & - \\
\hline eugenol $*$ & 1358 & - & 0.2 & - & - & - & - \\
\hline neryl acetate * & 1366 & - & - & - & - & - & 1.3 \\
\hline$\alpha$-copaene ${ }^{*}$ & 1377 & 0.1 & 0.2 & 0.3 & - & - & - \\
\hline geranyl acetate * & 1385 & 0.6 & - & - & - & - & 2.4 \\
\hline$\beta$-bourbonene & 1386 & - & - & 0.2 & 0.5 & - & - \\
\hline$\beta$-elemene * & 1392 & - & - & 0.2 & - & - & - \\
\hline (Z)-jasmone * & 1395 & - & 1.6 & - & - & - & - \\
\hline cis,cis-nepetalactone & 1397 & - & - & - & - & 0.1 & - \\
\hline$\beta$-caryophyllene * & 1419 & 0.2 & 0.2 & 1.7 & 0.6 & 0.1 & 0.3 \\
\hline$\alpha$-humulene ${ }^{*}$ & 1455 & 0.2 & - & 1.2 & 0.5 & 0.1 & - \\
\hline$(E)-\beta$-farnesene $*$ & 1459 & 0.1 & - & - & - & - & 0.1 \\
\hline trans-cadina-1(6),4-diene & 1475 & - & - & 1.0 & - & - & - \\
\hline$\gamma$-muurolene & 1478 & 0.2 & - & 0.5 & 0.2 & - & - \\
\hline
\end{tabular}


Table 2. Cont.

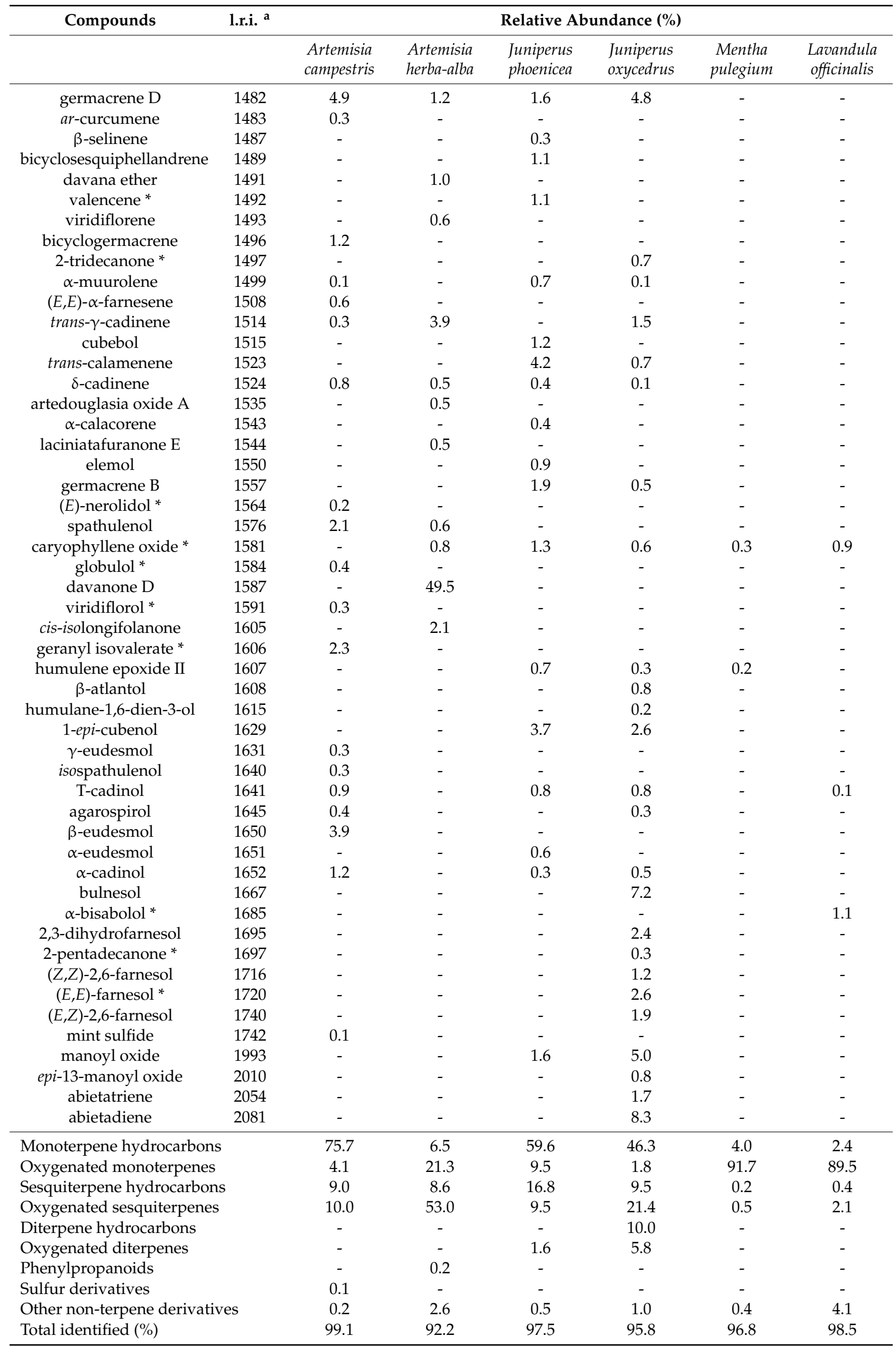

${ }^{a}$ Linear retention indices on a HP-5MS capillary column; ${ }^{b}$ Not detected; * Components for which the pure compound was injected for confirmation. 


\subsection{Antioxidant Activity}

The EOs antioxidant activity is reported in Table 3: it was evaluated as 2,2'-diphenyl1-picrylhydrazyl (DPPH) free radical scavenging activity, ferric-reducing/antioxidant power (FRAP) and 2,2' -azino-bis(3-ethylbenzothiazoline-6-sulphonic acid (ABTS) radical scavenging activity assays.

Table 3. In vitro antioxidant activities of the EOs of the six selected Algerian plants evaluated by 2,2'-diphenyl-1-picrylhydrazyl (DPPH), ferric-reducing/antioxidant power (FRAP) and 2,2'-azino-bis(3-ethylbenzothiazoline-6-sulphonic acid (ABTS) assays.

\begin{tabular}{|c|c|c|c|}
\hline SAMPLE & $\begin{array}{c}\text { DPPH } \\
\text { (IC50; } \mathrm{mg} / \mathrm{mL})\end{array}$ & $\begin{array}{c}\text { FRAP } \\
(\mu \mathrm{mol} \text { TX/g sample) }\end{array}$ & $\begin{array}{c}\text { ABTS } \\
\text { ( } \mu \mathrm{mol} \mathrm{TX/g} \mathrm{sample)}\end{array}$ \\
\hline A. campestris & $7.80 \pm 0.05^{\mathrm{D}}$ & $2.48 \pm 0.05^{C}$ & $7.01 \pm 0.09 \mathrm{~A}$ \\
\hline A. herba-alba & $2.61 \pm 0.01^{\mathrm{E}}$ & $8.17 \pm 0.15^{\mathrm{A}}$ & $6.74 \pm 0.10^{\mathrm{B}}$ \\
\hline J. phoenicea & $15.15 \pm 1.07^{\mathrm{C}}$ & $2.85 \pm 0.08^{C}$ & $5.50 \pm 0.04^{\mathrm{D}}$ \\
\hline J. oxycedrus & $91.25 \pm 3.40^{\mathrm{A}}$ & $0.97 \pm 0.03^{\mathrm{D}}$ & $5.82 \pm 0.15^{C}$ \\
\hline M. pulegium & $3.07 \pm 0.08^{\mathrm{E}}$ & $5.31 \pm 1.02^{\mathrm{B}}$ & $6.67 \pm 0.07^{B}$ \\
\hline L. officinalis & $27.36 \pm 1.25^{\mathrm{B}}$ & $3.56 \pm 0.09 C$ & $2.40 \pm 0.01^{\mathrm{E}}$ \\
\hline Ascorbic acid & $0.0030 \pm 0.0002$ & $7101 \pm 5.32$ & $26,835.87 \pm 11.245$ \\
\hline
\end{tabular}

Data (positive control excluded) were subjected to one-way ANOVA. Means within a column followed by different uppercase superscript letters are significantly different ( $p \leq 0.05$ according to Tukey's test).

In all the antioxidant assays, all the EOs exhibited a lower antioxidant power compared to ascorbic acid, used as a positive control. A. herba-alba EO had the highest antioxidant activity in both the DPPH and the FRAP assays. A high Pearson's correlation coefficient (0.82) was found between DPPH and FRAP values. However, such high correlation values could not be obtained in the case of ABTS test results, which evidenced $A$. campestris as the best-performing antioxidant EO. J. oxycedrus EO scored the lowest antioxidant power in both the DPPH and FRAP assays.

\subsection{Acetylcholinesterase (AChE), Butyrylcholinesterase (BuChE) and Tyrosinase Inhibitory Activities}

The EOs inhibitory activity on the three selected enzymes is reported in Table 4 . All the tested EOs exhibited inhibiting activities lower than the control standard in all the enzymatic assays. In the AChE inhibition assay, L. officinalis EO was detected as the best-performing, followed by M. pulegium EO. M. pulegium EO, instead, was the most active sample in the BuChE inhibition assay, with a rate close to the positive control. In both the $\mathrm{AChE}$ and $\mathrm{BuChE}$ inhibition assays, A. campestris and J. phoenicea EOs exhibited the lowest inhibitory activity among the six EOs. With the exception of J. phoenicea, all the EOs showed a similar degree (around 30\%) of tyrosinase inhibition potential.

Table 4. Tyrosinase, acetyl and butyl cholinesterase (AChE and BuChE) inhibitory activities of the EOs of the six selected Algerian plants.

\begin{tabular}{cccc}
\hline SAMPLE & $\begin{array}{c}\text { Tyrosinase Inhibition } \\
\text { Rate (\%) }\end{array}$ & $\begin{array}{c}\text { AChE Inhibition Rate } \\
\mathbf{( \% )}\end{array}$ & $\begin{array}{c}\text { BuChE Inhibition Rate } \\
\text { (\%) }\end{array}$ \\
\hline A. campestris & $38.36 \pm 3.86^{\mathrm{B}, \mathrm{C}}$ & $53.95 \pm 5.55^{\mathrm{D}}$ & $14.27 \pm 0.05^{\mathrm{D}}$ \\
A. herba-alba & $31.35 \pm 2.77^{\mathrm{C}}$ & $56.60 \pm 2.35^{\mathrm{C}, \mathrm{D}}$ & $72.03 \pm 2.49^{\mathrm{B}}$ \\
J. phoenicea & $11.35 \pm 1.45^{\mathrm{D}}$ & $40.57 \pm 5.07^{\mathrm{E}}$ & $6.47 \pm 1.25^{\mathrm{D}}$ \\
J. oxycedrus & $39.65 \pm 3.72^{\mathrm{B}}$ & $65.88 \pm 2.15^{\mathrm{B}, \mathrm{C}}$ & $37.49 \pm 3.95^{\mathrm{C}}$ \\
M. pulegium & $30.76 \pm 4.57^{\mathrm{C}}$ & $67.69 \pm 3.75^{\mathrm{B}}$ & $95.53 \pm 5.87^{\mathrm{A}}$ \\
L. officinalis & $32.28 \pm 1.01^{\mathrm{B}, \mathrm{C}}$ & $73.60 \pm 3.85^{\mathrm{A}, \mathrm{B}}$ & $68.32 \pm 4.25^{\mathrm{B}}$ \\
Kojic acid & $87.54 \pm 1.00^{\mathrm{A}}$ & - & - \\
Galantamine & - & $82.40 \pm 0.55^{\mathrm{A}}$ & $97.1 \pm 0.95^{\mathrm{A}}$ \\
\hline
\end{tabular}

The inhibition rates for all samples were calculated for their $1 \mathrm{mg} / \mathrm{mL}$ of concentration. The standard inhibitor kojic acid was only used at $0.05 \mathrm{mg} / \mathrm{mL}$ in the anti-tyrosinase assay. The standard inhibitor galantamine was also used at $0.004 \mathrm{mg} / \mathrm{mL}$ for anticholinesterase tests. BuChE: Butyrylcholinesterase; AChE: Acetylcholinesterase. Data were subjected to one-way ANOVA. Means within a column followed by different uppercase superscript letters are significantly different ( $p \leq 0.05$ according to Tukey's test). 


\subsection{Cytotoxic Activity}

The EOs anticancer activities were evaluated on three human cancer cell lines, including two human breast adenocarcinoma (MCF-7 and T-47D) and one human colon cancer (Caco-2) cell lines. The $\mathrm{LD}_{50}$ values, labeled as the concentration at which $50 \%$ of cell growth is inhibited, are presented in Table 5. Results indicated that the $\mathrm{LD}_{50}$ values were in the range of $0.016-0.99 \mathrm{mg} / \mathrm{mL}$, with the MCF-7 cancer cell line as the most responsive to treatment. A. herba-alba EO demonstrated the most potent activity among the examined EOs.

Table 5. Cytotoxic activities of the EOs of the six selected Algerian plants against two human breast adenocarcinoma (MCF-7 and T-47D) and one human colon cancer (Caco-2) cell lines. Results are expressed as $\mathrm{LD}_{50}(\mathrm{mg} / \mathrm{mL}) \pm \mathrm{SD}$.

\begin{tabular}{cccc}
\hline SAMPLE & MCF-7 & T47D & Caco-2 \\
\hline A. campestris & $0.28 \pm 0.06^{\mathrm{B}}$ & $0.43 \pm 0.04^{\mathrm{D}}$ & $0.76 \pm 0.09^{\mathrm{C}}$ \\
A. herba-alba & $0.016 \pm 0.005^{\mathrm{C}}$ & $0.08 \pm 0.005^{\mathrm{E}}$ & $0.19 \pm 0.03^{\mathrm{D}}$ \\
J. phoenicea & $0.32 \pm 0.2^{\mathrm{B}}$ & $0.64 \pm 0.05^{\mathrm{C}}$ & $0.98 \pm 0.10^{\mathrm{A}, \mathrm{B}}$ \\
J. oxycedrus & $0.70 \pm 0.02^{\mathrm{A}}$ & $0.98 \pm 0.04^{\mathrm{A}}$ & $0.99 \pm 0.07^{\mathrm{A}}$ \\
M. pulegium & $0.37 \pm 0.05^{\mathrm{B}}$ & $0.64 \pm 0.08^{\mathrm{C}}$ & $0.91 \pm 0.10^{\mathrm{A}, \mathrm{B}, \mathrm{C}}$ \\
L. officinalis & $0.68 \pm 0.04^{\mathrm{A}}$ & $0.84 \pm 0.07^{\mathrm{B}}$ & $0.79 \pm 0.03^{\mathrm{B}, \mathrm{C}^{\mathrm{C}}}$ \\
Doxorubicin & $0.005 \pm 0.0001^{\mathrm{C}}$ & $0.009 \pm 0.0004^{\mathrm{E}}$ & $0.015 \pm 0.003^{\mathrm{D}}$ \\
\hline
\end{tabular}

Data were subjected to one-way ANOVA. Means within a column followed by different uppercase superscript letters are significantly different ( $p \leq 0.05$ according to Tukey's test).

\section{Discussion}

A. campestris EO exhibited a predominance of oxygenated monoterpenes, differing from what was reported for an accession from South-East Morocco, in whose EO composition oxygenated sesquiterpenes were detected as the most abundant class of compounds, with spathulenol and $\beta$-eudesmol as the most represented [62]. For $\beta$-pinene, the most abundant compound in this EO, a broad range of biologic activities are reported, such as antimicrobial [63], anticonvulsant [64], gastroprotective [65], antioxidant [66] and neuroprotective [64]. Moreover, its combination with paclitaxel showed a synergistic effect on non-small-cell lung cancer (NSCLC), thus confirming the importance of the evaluation of the combined use of EOs rich in compounds with reported in vitro anti-proliferative activity in cancer chemotherapy [67]. Compositional differences with published literature also emerged in the EO of A. herba-alba; while the accession of the present study was mainly composed of oxygenated sesquiterpenes, specimens from Algeria [34,37] and Morocco [68] were reported as predominantly composed of oxygenated monoterpenes. J. phoenicea, instead, showed the same $\alpha$-pinene chemotype as reported for five specimens from Eastern Algeria [28] and one from the Boulmane region of Morocco [69]. The other Juniperus species studied in the present work presented a pulegone chemotype, as previously published analyses performed on accessions from Tunisia [29], Central Italy [70], Bulgaria and Serbia [71]. A predominance of sesquiterpenes, followed by diterpenes, was, instead, reported for a Tunisian accession of J. oxycedrus [70]. A pulegone chemotype was also found, in this study, for M. pulegium, in accordance with Sbayou et al. (2016) and Politeo et al. (2018), who analyzed the composition of two EOs of Iranian and Bosnia-Herzegovina specimens, respectively [68,72]. This oxygenated monoterpene exhibited the ability to inhibit the chemical and thermal nociceptive central perception in vivo [73]. An accession from North-West Iran, instead, was reported as mainly rich in menthone, thus exhibiting the second possible chemotype for this species [54]. The predominance of the oxygenated monoterpenes class found for L. officinalis EO of the present study was also reported by Marín et al. (2016), who analyzed an EO a Spanish accession [74]; moreover, linalool was reported as the main constituent of the flower EO of an Iranian specimen [75], while its acetic ester was predominant in a Brazilian accession [76]. Instead, 1,8-cineole and borneol were reported as the most abundant components of the EOs extracted from other two 
Iranian specimens [50,77]. Algerian L. officinalis, with its linalool-rich EO, may be considered a source of this oxygenated monoterpene, for which a wide range of bioactivities are reported, such as anti-inflammatory, anticancer, anti-hyperlipidemic, antimicrobial, antinociceptive, analgesic, anxiolytic, antidepressant and neuroprotective [78].

The highest antioxidant activity of $A$. herba-alba in the DPPH and FRAP assays may be due to its relevant $(10.0 \%)$ relative abundance of camphor, reported as favorable in terms of antioxidant power in an Artemisia judaica EO [79]. Its higher antioxidant activity in the ABTS assay may be due to the predominance of oxygenated terpenes, reported as more effective in neutralizing free radicals, quenching singlet and triplet oxygen, decomposing peroxides and chelating transition metals [80]. The lowest antioxidant power shown by J. oxycedrus EO, instead, may be due to its high relative content (over 35\%) of $\alpha$-pinene, for which a negative relationship with the antioxidant activity has been reported [81]. The contribution of single EO compounds to their antioxidant activity is still object of many debates. Mimica-Dukic et al. (2003) and Yadegarinia et al. (2006) reported that oxygenated monoterpenes act as radical scavenging compounds [82,83]. Ruberto and Baratta (2000), instead, indicated monoterpene hydrocarbons as responsible compounds for the antioxidant activity [84]. The importance of compounds in lower relative abundances, though, must be taken into account, considering the overall activity of the EOs with a more holistic approach, in which the phytocomplex acts as the result of the contribution of all the single components, which, ultimately, are effective in synergy [85]. Moreover, there are reports of quantitatively minor components exerting the antioxidant activity over the most abundant ones [86].

The inhibitory activity of the selected EOs on acetylcholinesterase (AChE) and butyrylcholinesterase $(\mathrm{BuChE})$ cholinesterase $(\mathrm{ChE})$ were studied since these enzymes have a fundamental role in the nervous system, as they are responsible for the hydrolysis of ACh [87]. L. officinalis and M. pulegium EOs, both rich in oxygenated terpenes, showed the highest inhibitory potency on AChE. This is in accordance with Benabdallah et al. (2018), who reported this chemical class of compounds and especially 1,8-cineole, whose highest relative abundance in the samples of the present study was found in L. officinalis EO, as the reason for the AChE inhibition activity [88]. Miyazawa et al. (1998) and Öztürk (2012) also attributed the AchE potency of Mentha spp. EOs to their oxygenated monoterpene fraction $[89,90]$. Monoterpenoids, indeed, may act as competitive or non-competitive inhibitors of the cholinesterase enzymes, with which they may be able to interact, due to their lipophilicity, on their hydrophobic sites [91]. M. pulegium EO was also found as the most active inhibitor of BuChE; since this enzyme increases in patients' brains as the Alzheimer's disease (AD) progresses, this result on the BuChE inhibiting activity is important, as this cholinesterase may be a better target for the AD therapy compared to AChE, especially in the late stages of the disorder [92]. The lowest inhibitor activity towards these enzymes was found for A. campestris and J. phoenicea EOs; their compositions showed a lower presence of oxygenated monoterpenes in favor of a higher relative content of their hydrocarbon counterparts. However, exactly like the antioxidant power of EOs, their inhibiting activity on cholinesterase enzymes is most probably due to their complete composition, in which the phytocomplex compounds act in synergy [89,93].

The EOs of the selected species were also tested for their inhibitory activity on tyrosinase: as this enzyme is involved in the first steps of melanin biosynthesis inside the melanocytes [94], its inhibition may be used to modulate skin pigmentation in hyperpigmentation disorders. Moreover, alterations in this biosynthetic step are involved in the development of some histopathological features of malignant metastatic melanoma, thus its inhibition represents a viable target to treat skin cancer [95]. EOs ability to inhibit this enzyme has been reported as competitive, non-competitive or mixed, based on their chemical composition [96]. Due to the complexity of the EO compositions, this activity is most probably attributable to a synergistic interaction of their compounds with the enzyme, rather than to a single component $[97,98]$. Contrary to published reports $[96,99]$, however, the anti-tyrosinase activity does not seem correlated to the oxygenated monoterpenes fraction in the EOs composition: the two 
best performing ones in our assay were, indeed, the EOs with the lowest relative abundances of this chemical class of compounds.

The MCF-7 (human breast adenocarcinoma) cancer cell line was the most responsive to the EO treatments. A. herba-alba EO showed the highest cytotoxic potency. This may be explained by its high davanone D content, whose relative content added up to almost $50 \%$ of the EO. For this compound and its derivatives, anti-proliferative and pro-apoptotic effects are reported for several cancer cell lines, included MCF-7 [100]. Moreover, its unique chemical composition is rich in known naturally occurring anticancer chemical ingredients such as $\alpha$-thujone (28.1\%), camphor (22.8\%) and 1,8-cineole $(8.2 \%)$ [101]. There are very few published studies in the literature that reported the anticancer activity of A. herba-alba EO. Our results demonstrated that the essential oil had significant anticancer activity against the examined breast and colon cancer cells. The observed activity started at very low EO concentrations (lower than $5 \mu \mathrm{g} / \mathrm{mL}$ ), while more than $80 \%$ of the cells were in the lysis phase at high concentration $(300 \mu \mathrm{g} / \mathrm{mL})$, suggesting a great potential for a naturally occurring chemotherapeutic or chemo-preventive agent.

\section{Materials and Methods}

\subsection{Plant Material}

For all the species, $1 \mathrm{~kg}$ of aerial parts was individually collected at fruiting stage during May-July 2018 in Laghouat, Algeria (Latitude: 33 $47^{\prime} 59^{\prime \prime}$, Longitude: $2^{\circ} 51^{\prime} 54^{\prime \prime}$, Altitude: $764 \mathrm{~m}$ ). The identification and authentication of the plants were carried out by the botanist Dr. Mohamed Kouidri (Department of Agronomy, Faculty of Sciences, University of Laghouat, Laghouat, Algeria) and the voucher specimens were deposited at the Laboratory of Process Engineering, University of Laghouat, Algeria with the numbers LGP Ac/07/18, LGP Ah/07/18, LGP Jp/05/18, LGP Jo/05/18, LGP Mp/06/18 and LGP Lo/06/18, respectively for Artemisia campestris, Artemisia herba-alba, Juniperus phoenicea, Juniperus oxycedrus, Mentha pulegium and Lavandula officinalis.

\subsection{Essential Oil Extractions}

For each species, $100 \mathrm{~g}$ of air-dried aerial parts of the collected plants was hydrodistilled for $3 \mathrm{~h}$ using a Clevenger-type apparatus. The obtained essential oils (EOs) were dried over anhydrous sodium sulphate and, after filtration, stored at $4{ }^{\circ} \mathrm{C}$ until analysis.

\subsection{Gas Chromatography-Mass Spectrometry Analyses and Peaks Identification}

The hydrodistilled essential oils were diluted to $0.5 \%$ in HPLC-grade $n$-hexane and then injected into a GC-MS apparatus. Gas chromatography-electron impact mass spectrometry (GC-EIMS) analyses were performed with an Agilent 7890B gas chromatograph (Agilent Technologies Inc., Santa Clara, CA, USA) equipped with an Agilent DB-5MS (Agilent Technologies Inc., Santa Clara, CA, USA) capillary column $(30 \mathrm{~m} \times 0.25 \mathrm{~mm}$; coating thickness $0.25 \mu \mathrm{m})$ and an Agilent 5977B single quadrupole mass detector (Agilent Technologies Inc., Santa Clara, CA, USA). The analytical conditions were as reported in Zardi-Bergaoui et al. (2018) [102]: injector and transfer line temperatures 220 and $240{ }^{\circ} \mathrm{C}$, respectively; oven temperature programmed from 60 to $240{ }^{\circ} \mathrm{C}$ at $3{ }^{\circ} \mathrm{C} / \mathrm{min}$; carrier gas helium at $1 \mathrm{~mL} / \mathrm{min}$; injection of $1 \mu \mathrm{L}$ (0.5\% HPLC grade $n$-hexane solution); split ratio 1:25. The acquisition parameters were as follows: full scan; scan range: $30-300 \mathrm{~m} / \mathrm{z}$; scan time: $1.0 \mathrm{~s}$.

The GC analyses were accomplished with a HP-5890 Series II instrument (Agilent Technologies Inc., Santa Clara, CA, USA) equipped with a HP-5 (Agilent Technologies Inc., Santa Clara, CA, USA) capillary columns ( $30 \mathrm{~m} \times 0.25 \mathrm{~mm}, 0.25-\mu \mathrm{m}$ film thickness), set to the following conditions: temperature program of $60^{\circ} \mathrm{C}$ for $10 \mathrm{~min}$, followed by an increase of $3{ }^{\circ} \mathrm{C} / \mathrm{min}$ to $220^{\circ} \mathrm{C}$; injector and detector temperatures at $250{ }^{\circ} \mathrm{C}$; carrier gas helium ( $\left.1 \mathrm{~mL} / \mathrm{min}\right)$; detector FID; split ratio 1:30). The relative proportions of the individual constituents, expressed as percentages, were obtained by FID peak-area normalization. 
As reported in Mosbah et al. (2018) [103], the identification of the constituents was based on the comparison of the retention times with those of authentic samples, comparing their linear retention indices relative to the series of $n$-hydrocarbons, and on computer matching against commercial (NIST 2014 and ADAMS 2007) and home-made library mass spectra built up from pure substances and components of commercial essential oils of known composition and MS literature data [104-106].

\subsection{Antioxidant Assays}

\subsubsection{DPPH Free Radical Scavenging Activity}

The DPPH free radical scavenging activity of the hydrodistilled essential oils was evaluated by bleaching of the purple-colored methanol solution of 2,2'-diphenyl-1-picrylhydrazyl (DPPH) at $517 \mathrm{~nm}$ after the addition of extract at different concentrations as antioxidant agents to the DPPH solution. The inhibition concentration values obtained for each concentration was calculated using following equation:

$$
\text { Inhibition concentration }(\%)=\left[\left(\mathrm{A}_{\text {blank }}-\mathrm{A}_{\text {sample }}\right) / \mathrm{A}_{\text {blank }}\right] \times 100
$$

$\mathrm{IC}_{50}$ values (extract concentrations providing 50\% inhibition) were also calculated [107].

\subsubsection{Ferric-Reducing/Antioxidant Power}

The FRAP assay was performed following the method based on the principle of reducing the Fe (III)-TPTZ complex in the presence of antioxidants to form blue Fe (II)-TPTZ complex and the subsequent measurement of the maximum absorbance at $595 \mathrm{~nm}$ [108]. For this purpose, appropriate amounts of the essential oil or Trolox standard were combined with the FRAP reagent ( $300 \mathrm{mM}$ acetate buffer (pH 3.6), $10 \mathrm{mM}$ 2,4,6-tripyridyl-s-triazine (TPTZ) solution prepared in 40-mM HCl and 20-mM $\mathrm{FeCl}_{3} \cdot 6 \mathrm{H}_{2} \mathrm{O}$ in a 10:1:1 ratio just before use and heated to $37^{\circ} \mathrm{C}$ ). The mixtures were incubated at $37^{\circ} \mathrm{C}$ for $30 \mathrm{~min}$, then the resulting absorbances were measured at $593 \mathrm{~nm}$. FRAP values for samples were calculated as Trolox equivalents ( $\mu \mathrm{mol} \mathrm{TX} / \mathrm{g}$ sample).

\subsubsection{ABTS Radical Scavenging Activity}

The ABTS radical scavenging activity was determined according to the method described by Re et al. (1999) [109] with some modifications. The ABTS solution was prepared by dissolving ABTS (2,2'-azino-bis(3-ethylbenzothiazoline-6-sulphonic acid) in water to a 7-mM concentration. ABTS radical cation (ABTS + ) was also produced by reacting ABTS solution with $2.45 \mathrm{mM}$ potassium persulfate (final concentration) and allowing the mixture to stand in the dark at room temperature for 12-16 $\mathrm{h}$ before use. Then, the absorbance of the final ABTS radical solution was adjusted to 0.7 at $734 \mathrm{~nm}$. The essential oil samples or Trolox standards at appropriate concentrations were combined with the stabilized radical solution and incubated at $30{ }^{\circ} \mathrm{C}$. After $30 \mathrm{~min}$, the absorbances were spectrophotometrically measured at $734 \mathrm{~nm}$. Results were expressed as Trolox equivalents $(\mu \mathrm{mol} \mathrm{TX} / \mathrm{g}$ sample). Ascorbic acid was used as positive control.

\subsection{Inhibitory Activity on $A C h E$ and BuChE Enzymes}

Acetylcholinesterase $(\mathrm{AChE})$ and butyrylcholinesterase $(\mathrm{BuChE})$ inhibitory activities were measured by following the method developed by Ellman et al. (1961) [110]. Electric eel AChE and $\mathrm{BuChE}$ from equine serum were used as enzymes, while acetylthiocholine iodide and butyrylthiocholine chloride were used as substrates. The reaction mixture was first prepared to contain $0.2 \mathrm{M}$ 5,5'-dithio-bis(2-nitrobenzoic) acid (DTNB) and 0.2-M enzyme solution in the presence of the sample tested as an inhibitor or of the standard inhibitor and incubated for $15 \mathrm{~min}$ at $25^{\circ} \mathrm{C}$. The reaction was then initiated with the addition of $0.2 \mathrm{M}$ of each substrate. The hydrolysis of the substrates was monitored by the formation of the yellow 5-thio-2-nitrobenzoate anion as a result of the reaction 
of DTNB with thiocholines, catalyzed by enzymes at $412 \mathrm{~nm}\left(\mathrm{Abs}_{\text {sample }}\right)$. AChE/BuChE inhibition percentage was determined by comparison of the reaction rates of the samples relative to a blank sample (methanol as extraction solvent in phosphate buffer, $\mathrm{pH} 8$ ) using the following equation:

$$
\text { Inhibition ratio }(\%)=\left[\left(\mathrm{Abs}_{\text {blank }}-\mathrm{Abs}_{\text {sample }}\right) / \mathrm{Abs}_{\text {blank }}\right] \times 100
$$

Galantamine, an alkaloid-type anticholinesterase, was used as positive control.

\subsection{Anti-Tyrosinase Activity}

To evaluate the anti-tyrosinase activity of the essential oils, mushroom tyrosinase $(0.5 \mathrm{mg} / \mathrm{mL})$ was first incubated with each extract in phosphate buffer $(50 \mathrm{mM}, \mathrm{pH}$ 6.8) for $20 \mathrm{~min}$ at room temperature. Following incubation, $0.5 \mathrm{mM}$ of L-DOPA as substrate was added to this mixture and the change in absorbance at $475 \mathrm{~nm}$ as an indication of the enzymatic reaction due to formation of DOPA chrome was monitored. The percent of inhibition of tyrosinase reaction was calculated by using the same equation used for $\mathrm{AChE} / \mathrm{BuChE}$ inhibition activity. Kojic acid was used as reference standard inhibitor for comparison [111].

\subsection{Cytotoxic Activity}

All cell lines (MCF7, T47D and Caco-2) were purchased from the American Type Culture Collection (Rockville, MD, USA). Cells were cultured in DMEM medium (Dulbecco's Modified Eagle's Medium), supplemented with $10 \%$ fetal bovine serum, $100 \mathrm{U} / \mathrm{mL}$ of penicillin, $100 \mu \mathrm{g} / \mathrm{mL}$ of streptomycin, at $37^{\circ} \mathrm{C}$ with $5 \%$ of $\mathrm{CO}_{2}$. The count of viable cells was determined using the Trypan blue method, as previously described [112]. The cytotoxic effects of the examined oils were evaluated using the MTT assay (3-[4, 5-dimethylthiazole-2-yl]-2,5-diphenyl-tetrazolium bromide) (Sigma-Aldrich, St. Louis, MO, USA), as previously described [112]. The essential oils were tested for their cytotoxic activity in the concentration range of $0.001-10 \mathrm{mg} / \mathrm{mL}$. Doxorubicin was employed as a positive control; the preparation and the treatment were performed in the same experimental conditions for the control and the test samples. Prism 8 software (GraphPad Software, San Diego, CA, USA) was utilized for data analysis to calculate inhibition percentages and the results were expressed as $\mathrm{LD}_{50}$ value, defined as the concentration that resulted in $50 \%$ growth inhibition of the cancer cell culture.

\subsection{Statistical Analysis}

All analyses were performed with the JMP ${ }^{\circledR}$ Pro 13.2.1 (SAS Institute Inc., Cary, NC, USA) software. All the assays were performed in triplicate. The results are expressed as mean \pm standard deviation (SD). The statistical significance of data in Tables $3-5$ was evaluated using Tukey's honest significance test (HSD), with $\alpha=0.05$.

\section{Conclusions}

Among the EOs studied in the present work, of all extracted from plants belonging to the Algerian flora, the highest antioxidant activity was evidenced for A. herba-alba and M. pulegium in both the DPPH and FRAP assays, while A. campestris showed the highest antioxidant power in the ABTS test.

M. pulegium EO also exhibited the strongest inhibiting power in the BuChE inhibition assay, while the best inhibitory effect on the AChE enzyme was evidenced for $L$. officinalis EO. The highest tyrosinase inhibition rates were found for J. oxycedrus and A. campestris. Finally, A. herba-alba EO exhibited remarkable cytotoxic effects on MCF-7, T47D and Caco-2 cancer cell lines.

These species should, thus, be re-evaluated as sources of value-added products such as EOs, whose numerous possible applications are based on their whole compositions, rather than on a single purified compound, isolated from the complete EO. Their application may range from food preservation-given their antioxidant power-to possible candidates to be added in the therapy of Alzheimer's disease, as well as in cancer treatment. Further studies are needed to assess their efficacy in vivo. Moreover, close 
attention must be paid to the starting plant material, as many factors contribute to the overall chemical composition of the EOs: to ensure the best possible standardization of their chemical composition, indeed, the variations in the involved factors (genetic profile, geographical provenience, harvesting time, etc.) should be minimized.

Author Contributions: B.B. and M.A.G. conceived and designed the experiments, searched information, analyzed it and wrote the original paper; K.C. and A.G. collected the plant material and prepared the essential oils; G.F. and R.A. performed the GC-MS analysis and revised the manuscript; M.C.A. performed the biologic assays and statistical analysis; S.K.B. determined and discussed the cytotoxic activity. All authors have read and agreed to the published version of the manuscript

Funding: This research received no external funding.

Acknowledgments: This work was supported by the Algerian Ministry of Higher Education and Scientific Research "Program A16N01UN030120180002".

Conflicts of Interest: The authors declare no conflict of interest.

\section{References}

1. Falcão, S.; Bacém, I.; Igrejas, G.; Rodrigues, P.J.; Vilas-Boas, M.; Amaral, J.S. Chemical composition and antimicrobial activity of hydrodistilled oil from juniper berries. Ind. Crops Prod. 2018, 124, 878-884. [CrossRef]

2. Saad, A.M.; Mohammed, M.M.D.; Ghareeb, M.A.; Ahmed, W.S.; Farid, M.A. Chemical Composition and Antimicrobial Activity of the Essential Oil of the Leaves of Cupressus macrocarpa Hartweg. ex Gordon. J. Appl. Pharm. Sci. 2017, 7, 207-212.

3. Ghareeb, M.A.; Refahy, L.A.; Saad, A.M.; Ahmed, W.S. Chemical composition, antioxidant and anticancer activities of the essential oil from Eucalyptus citriodora (Hook.) leaves. Der Pharma Chem. 2016, 8, 192-200.

4. Tefiani, C.; Riazi, A.; Youcefi, F.; Aazza, S.; Gago, C.; Faleiro, M.L.; Pedro, L.G.; Barroso, J.G.; Figueiredo, A.C.; Megías, C.; et al. Ammoides pusilla (Apiaceae) and Thymus munbyanus (Lamiaceae) from Algeria essential oils: Chemical composition, antimicrobial, antioxidant and antiproliferative activities. J. Essent. Oil Res. 2015, 27, 131-139. [CrossRef]

5. Meira, C.S.; Guimarães, E.T.; Macedo, T.S.; da Silva, T.B.; Menezes, L.R.A.; Costa, E.V.; Soares, M.B.P. Chemical composition of essential oils from Annona vepretorum Mart. and Annona squamosa L. (Annonaceae) leaves and their antimalarial and trypanocidal activities. J. Essent. Oil Res. 2015, 27, 160-168. [CrossRef]

6. Hussein, M.A.; Gobba, N.A.; Helmy, M. Composition, in vitro antioxidant and antitumor properties of essential oil from the seeds of Moringa oleifera. Int. J. Pharma Bio Sci. 2014, 4, 532-540.

7. Ghareeb, M.A.; Mohamed, T.; Saad, A.M.; Refahy, L.A.-G.; Sobeh, M.; Wink, M. HPLC-DAD-ESI-MS/MS analysis of fruits from Firmiana simplex (L.) and evaluation of their antioxidant and antigenotoxic properties. J. Pharm. Pharmacol. 2018, 70, 133-142. [CrossRef]

8. Ghareeb, M.; Sobeh, M.; Rezq, S.; El-Shazly, A.; Mahmoud, M.; Wink, M. HPLC-ESI-MS/MS Profiling of Polyphenolics of a Leaf Extract from Alpinia zerumbet (Zingiberaceae) and Its Anti-Inflammatory, Anti-Nociceptive, and Antipyretic Activities In Vivo. Molecules 2018, 23, 3238. [CrossRef]

9. Ghareeb, M.; Saad, A.; Ahmed, W.; Refahy, L.; Nasr, S. HPLC-DAD-ESI-MS/MS characterization of bioactive secondary metabolites from Strelitzia nicolai leaf extracts and their antioxidant and anticancer activities in vitro. Pharmacognosy Res. 2018, 10, 368. [CrossRef]

10. Sobeh, M.; Mahmoud, M.F.; Hasan, R.A.; Abdelfattah, M.A.O.; Sabry, O.M.; Ghareeb, M.A.; El-Shazly, A.M.; Wink, M. Tannin-rich extracts from Lannea stuhlmannii and Lannea humilis (Anacardiaceae) exhibit hepatoprotective activities in vivo via enhancement of the anti-apoptotic protein Bcl-2. Sci. Rep. 2018, 8, 9343. [CrossRef]

11. Bakchiche, B.; Gherib, A.; Bronze, M.R.; Ghareeb, M.A. Identification, Quantification, and Antioxidant Activity of Hydroalcoholic Extract of Artemisia campestris from Algeria. Turkish J. Pharm. Sci. 2019, 16, 234-239. [CrossRef]

12. Terry, R.D.; Katzman, R.K. Senile dementia of the Alzheimer type. Ann. Neurol. 1983, 14, 497-506. [CrossRef] [PubMed]

13. Jaén, J.C.; Gregor, V.E.; Lee, C.; Davis, R.; Emmerling, M. Acetylcholinesterase inhibition by fused dihydroquinazoline compounds. Bioorg. Med. Chem. Lett. 1996, 6, 737-742. [CrossRef] 
14. Schneider, L.S. New therapeutic approaches to Alzheimer's disease. J. Clin. Psychiatry 1996, 57, 30-36. [PubMed]

15. Cummings, J.L.; Vinters, H.V.; Cole, G.M.; Khachaturian, Z.S. Alzheimer's disease: Etiologies, pathophysiology, cognitive reserve, and treatment opportunities. Neurology 1998, 51, S2-S17. [CrossRef]

16. Syad, A.N.; Shunmugiah, K.P.; Kasi, P.D. Assessment of Anticholinesterase Activity of Gelidiella acerosa: Implications for Its Therapeutic Potential against Alzheimer's Disease. Evid.-Based Complement. Altern. Med. 2012, 2012, 1-8. [CrossRef]

17. Elumalai, K.; Ali, M.A.; Elumalai, M.; Eluri, K.; Srinivasan, S. Acetylcholinesterase enzyme inhibitor activity of some novel pyrazinamide condensed 1,2,3,4-tetrahydropyrimidines. Biotechnol. Rep. 2015, 5, 1-6. [CrossRef]

18. Boulanouar, B.; Abdelaziz, G.; Aazza, S.; Gago, C.; Miguel, M.G. Antioxidant activities of eight Algerian plant extracts and two essential oils. Ind. Crops Prod. 2013, 46, 85-96. [CrossRef]

19. Boudjelal, A.; Henchiri, C.; Sari, M.; Sarri, D.; Hendel, N.; Benkhaled, A.; Ruberto, G. Herbalists and wild medicinal plants in $\mathrm{M}^{\prime}$ Sila (North Algeria): An ethnopharmacology survey. J. Ethnopharmacol. 2013, 148, 395-402. [CrossRef]

20. Sarri, M.; Zahra Mouyet, F.; Benziane, M.; Cheriet, A. Traditional use of medicinal plants in a city at steppic character (M'sila, Algeria). J. Pharm. Pharmacogn. Res. 2014, 2, 31-35.

21. Belhattab, R.; Amor, L.; Barroso, J.G.; Pedro, L.G.; Cristina Figueiredo, A. Essential oil from Artemisia herba-alba Asso grown wild in Algeria: Variability assessment and comparison with an updated literature survey. Arab. J. Chem. 2014, 7, 243-251. [CrossRef]

22. Menaceur, F.; Benchabane, A.; Hazzit, M.; Baaliouamer, A. Chemical Composition and Antioxidant Activity of Algerian Juniperus phoenicea L. Extracts. J. Biol. Act. Prod. Nat. 2013, 3, 87-96.

23. Dob, T.; Dahmane, D.; Chelghoum, C. Essential Oil Composition of Juniperus Oxycedrus Growing in Algeria. Pharm. Biol. 2006, 44, 1-6. [CrossRef]

24. Abdelli, M.; Moghrani, H.; Aboun, A.; Maachi, R. Algerian Mentha pulegium L. leaves essential oil: Chemical composition, antimicrobial, insecticidal and antioxidant activities. Ind. Crops Prod. 2016, 94, 197-205. [CrossRef]

25. Boughendjioua, H. Chemical composition and antibacterial activity of essential oil of Lavandula officinalis grown in the region of Skikda-Algeria. Bull. Soc. R. Sci. Liège 2017, 86, 88-95.

26. Adams, R.P. Systematics of the one seeded Juniperus of the eastern hemisphere based on leaf essential oils and random amplified polymorphic DNAs (RAPDs). Biochem. Syst. Ecol. 2000, 28, 529-543. [CrossRef]

27. Medini, H.; Manongiu, B.; Aicha, N.; Chekir-Ghedira, L.; Harzalla-Skhiri, F.; Khouja, M.L. Chemical and Antibacterial Polymorphism of Juniperus oxycedrus ssp. oxycedrus and Juniperus oxycedrus ssp. macrocarpa (Cupressaceae) Leaf Essential Oils from Tunisia. J. Chem. 2013, 2013, 1-8.

28. Ramdani, M.; Lograda, T.; Silini, H.; Zeraib, A.; Chalard, P.; Figueredo, G.; Bouchaala, M.; Zerrar, S. Antibacterial activity of Essential oils of Juniperus phoenicea from Eastern Algeria. J. Appl. Pharm. Sci. 2013, 3, 22-28.

29. Dahmane, D.; Dob, T.; Chelghoum, C. Chemical composition and analyses of enantiomers of essential oil obtained by steam distillation of Juniperus oxycedrus L. growing in Algeria. J. Mater. Environ. Sci. 2015, 6, 3159-3167.

30. Farjon, A. A Handbook of the World's Conifers (two vol. set); Brill Academic Publishers: Leiden, The Netherlands, 2010.

31. Amer, M.; Wasif, M.; Abo-Aytta, A. Chemical and biological evaluation of Juniperus phoenicea as a hypoglycaemic agent. J. Agric. Res. 1994, 21, 1077-1091.

32. Bellakhdar, J. Horizons Maghrébins_Le Droit à la Mémoire. Calligraphies. Hommage à Nja Mahdaoui; Persée: Lyon, France, 1998; pp. 319-321.

33. Allali, H.; Benmehdi, H.; Dib, M.; Tabti, B.; Ghalem, S.; Benabadji, N. Phytotherapy of Diabetes in West Algeria. Asian J. Chem. 2008, 20, 2701-2710.

34. Rekkab, S.; Abaza, I.; Chibani, S.; Kabouche, A.; Kabouche, Z. Chemical composition of the essential oil of aerial parts of Artemisia herba-alba Asso. from Oum El-Bouaghi (Algeria) and chemotaxonomic survey. J. Mater. Environ. Sci. 2016, 7, 4383-4390.

35. Segal, R.; Feuerstein, I.; Danin, A. Chemotypes of Artemisia herba-alba in Israel based on their sesquiterpene lactone and essential oil constitution. Biochem. Syst. Ecol. 1987, 15, 411-416. [CrossRef] 
36. Adel, K.; Zied, Z.; Ahmed, B.K.; Neacute Ji, G.; Mohamed, D.; Radhouane, G. Chemical constituents and antioxidant activity of the essential oil from aerial parts of Artemisia herba-alba grown in Tunisian semi-arid region. Afr. J. Biotechnol. 2011, 10, 2923-2929. [CrossRef]

37. Lakehal, S.; A, M. Essential Oil Composition and Antimicrobial Activity of Artemisia herba-alba Asso Grown in Algeria. Med. Chem. 2016, 6. [CrossRef]

38. Jouad, H.; Haloui, M.; Rhiouani, H.; El Hilaly, J.; Eddouks, M. Ethnobotanical survey of medicinal plants used for the treatment of diabetes, cardiac and renal diseases in the North centre region of Morocco (Fez-Boulemane). J. Ethnopharmacol. 2001, 77, 175-182. [CrossRef]

39. Tahraoui, A.; El-Hilaly, J.; Israili, Z.H.; Lyoussi, B. Ethnopharmacological survey of plants used in the traditional treatment of hypertension and diabetes in south-eastern Morocco (Errachidia province). J. Ethnopharmacol. 2007, 110, 105-117. [CrossRef]

40. Zeggwagh, N.A.; Michel, J.B.; Eddouks, M. Acute hypotensive and diuretic activities of Artemisia herba alba aqueous extract in normal rats. Asian Pac. J. Trop. Biomed. 2014, 4, S644-S648. [CrossRef]

41. Yashphe, J.; Feuerstein, I.; Barel, S.; Segal, R. The Antibacterial and Antispasmodic Activity of Artemisia herba alba Asso. II. Examination of Essential Oils from Various Chemotypes. Int. J. Crude Drug Res. 1987, 25, 89-96. [CrossRef]

42. Hatimi, S.; Boudouma, M.; Bichichi, M.; Chaib, N.; Idrissi, N.G. In vitro evaluation of antileishmania activity of Artemisia herba alba Asso. Bull. Soc. Pathol. Exot. 2001, 94, 29-31.

43. Iriadam, M.D.; Musa, G.M.; Hatice, H.; Sun Baba, F. Effects of two Turkish medicinal plants Artemisia herba-alba and Teucrium polium on blood glucose levels and other biochemical parameters in rabbits. J. Cell Mol. Biol. 2006, 5, 19-24.

44. Mighri, H.; Hajlaoui, H.; Akrout, A.; Najjaa, H.; Neffati, M. Antimicrobial and antioxidant activities of Artemisia herba-alba essential oil cultivated in Tunisian arid zone. Comptes Rendus Chim. 2010, 13, 380-386. [CrossRef]

45. Essid, R.; Rahali, F.Z.; Msaada, K.; Sghair, I.; Hammami, M.; Bouratbine, A.; Aoun, K.; Limam, F. Antileishmanial and cytotoxic potential of essential oils from medicinal plants in Northern Tunisia. Ind. Crops Prod. 2015, 77, 795-802. [CrossRef]

46. Dib, I.; Mihamou, A.; Berrabah, M.; Mekhfi, H.; Aziz, M.; Legssyer, A.; Bnouham, M.; Ziyyat, A. Identification of Artemisia campestris L. subsp glutinosa (Besser) Batt. from Oriental Morocco based on its morphological traits and essential oil profile. J. Mater. Environ. Sci. 2017, 8, 180-187.

47. Megdiche-Ksouri, W.; Trabelsi, N.; Mkadmini, K.; Bourgou, S.; Noumi, A.; Snoussi, M.; Barbria, R.; Tebourbi, O.; Ksouri, R. Artemisia campestris phenolic compounds have antioxidant and antimicrobial activity. Ind. Crops Prod. 2015, 63, 104-113. [CrossRef]

48. Dib, I.; Angenot, L.; Mihamou, A.; Ziyyat, A.; Tits, M. Artemisia campestris L.: Ethnomedicinal, phytochemical and pharmacological review. J. Herb. Med. 2017, 7, 1-10. [CrossRef]

49. Imelouane, B.; Elbachiri, A.; Ankit, M.; Benzeid, H.; Khedid, K. Physico-chemical compositions and antimicrobial activity of essential oil of Eastern Moroccan Lavandula dentata. Int. J. Agric. Biol. 2009, 11, 113-118.

50. Shafagat, A.; Salimi, F.; Amani-Hooshyar, V. Phytochemical and antimicrobial activities of Lavandula officinalis leaves and stems against some pathogenic microorganisms. J. Med. Plant Res. 2012, 6, 455-460.

51. El Hassouni, A.; El Bachiri, A.; Belbachir, C.; Tahini, A. Chemical composition, antioxidant and antibacterial activity of essential oil of Lavandula dentata growing wild in Morocco. Am. J. Innov. Res. Appl. Sci. 2017, 4, 208-213.

52. Cavanagh, H.M.A.; Wilkinson, J.M. Biological activities of Lavender essential oil. Phyther. Res. 2002, 16, 301-308. [CrossRef]

53. Sanz, J.; Soria, A.C.; Garcı-Vallejo, M.C. Analysis of volatile components of Lavandula luisieri L. by direct thermal desorption-gas chromatography-mass spectrometry. J. Chromatogr. A 2004, 1024, 139-146. [CrossRef] [PubMed]

54. Hassanpouraghdam, M.B.; Akhgari, A.B.; Aazami, M.A.; Emarat-Pardaz, J. New menthone type of Mentha pulegium L. volatile oil from northwest Iran. Czech. J. Food Sci. 2011, 29, 285-290. [CrossRef]

55. Božović, M.; Pirolli, A.; Ragno, R. Mentha suaveolens Ehrh. (Lamiaceae) Essential Oil and Its Main Constituent Piperitenone Oxide: Biological Activities and Chemistry. Molecules 2015, 20, 8605-8633. [CrossRef] [PubMed] 
56. Kumar, P.; Mishra, S.; Malik, A.; Satya, S. Insecticidal properties of Mentha species: A review. Ind. Crops Prod. 2011, 34, 802-817. [CrossRef]

57. Moreno, L.; Bello, R.; Primo-Yúfera, E.; Esplugues, J. Pharmacological properties of the methanol extract from Mentha suaveolens Ehrh. Phyther. Res. 2002, 16, 10-13. [CrossRef]

58. İşcan, G.; Kirimer, N.; Kürkcüoglu, M.; Hüsnü Can, B.; Demirci, F. Antimicrobial Screening of Mentha piperita Essential Oils. J. Agric. Food Chem. 2002, 50, 3943-3946.

59. Hajlaoui, H.; Trabelsi, N.; Noumi, E.; Snoussi, M.; Fallah, H.; Ksouri, R.; Bakhrouf, A. Biological activities of the essential oils and methanol extract of tow cultivated mint species (Mentha longifolia and Mentha pulegium) used in the Tunisian folkloric medicine. World J. Microbiol. Biotechnol. 2009, 25, 2227-2238. [CrossRef]

60. Ceker, S.; Agar, G.; Alpsoy, L.; Nardemir, G.; Kizil, H.E.; Mete, E. Protective Role of Mentha longifolia L. ssp. longifolia against Aflatoxin B. J. Essent. Oil Bear. Plants 2013, 16, 600-607. [CrossRef]

61. Papadimitriou, D.M.; Petrakis, E.A.; Arvaniti, K.A.; Kimbaris, A.C.; Polissiou, M.G.; Perdikis, D.C. Comparative bioactivity of essential oils from two Mentha pulegium (Lamiaceae) chemotypes against Aphis gossypii, Aphis spiraecola, Tetranychus urticae and the generalist predator Nesidiocoris tenuis. Phytoparasitica 2019, 47, 683-692. [CrossRef]

62. Dib, I.; Fauconnier, M.-L.; Sindic, M.; Belmekki, F.; Assaidi, A.; Berrabah, M.; Mekhfi, H.; Aziz, M.; Legssyer, A.; Bnouham, M.; et al. Chemical composition, vasorelaxant, antioxidant and antiplatelet effects of essential oil of Artemisia campestris L. from Oriental Morocco. BMC Complement. Altern. Med. 2017, 17, 82. [CrossRef]

63. van Zyl, R.L.; Seatlholo, S.T.; van Vuuren, S.F.; Viljoen, A.M. The Biological Activities of 20 Nature Identical Essential Oil Constituents. J. Essent. Oil Res. 2006, 18, 129-133. [CrossRef]

64. Felipe, C.; Albuquerque, A.M.S.; De Pontes, J.L.X.; De Melo, J.; Ítalo, V.; Rodrigues, T.C.M.L.; De Sousa, A.M.P.; Monteiro, Á.B.; Ribeiro, A.E.D.S.; Lopes, J.P.; et al. PTZ-induced convulsions in mice. Fundam. Clin. Pharmacol. 2019, 33, 181-190. [CrossRef] [PubMed]

65. Matthews Jucá, D.; da Silva, M.; Palheta Junior, R.; de Lima, F.; Okoba, W.; Lahlou, S.; de Oliveira, R.; dos Santos, A.; Magalhães, P. The Essential Oil of Eucalyptus tereticornis and its Constituents, $\alpha$ - and $\beta$-Pinene, Show Accelerative Properties on Rat Gastrointestinal Transit. Planta Med. 2011, 77, 57-59. [CrossRef]

66. Sharopov, F.S.; Wink, M.; Setzer, W.N. Radical Scavenging and Antioxidant Activities of Essential Oil Components-An Experimental and Computational Investigation. Nat. Prod. Commun. 2015, 10, 1501000. [CrossRef]

67. Zhang, Z.; Guo, S.; Liu, X.; Gao, X. Synergistic Antitumor Effect of $\alpha$-pinene and $\beta$-pinene with Paclitaxel against Non-small-cell Lung Carcinoma (NSCLC). Drug Res. 2014, 65, 214-218. [CrossRef]

68. Sbayou, H.; Boumaza, A.; Hilali, A.; Amghar, S. Antioxidant properties of Artemisia herba-alba Asso., Mentha pulegium L. and Origanum compactum Benth. essential oils. J. Mater. Environ. Sci. 2016, 7, 2908-2912.

69. Derwich, E.; Benziane, Z.; Boukir, A. Chemical Composition of Leaf Essential Oil of Juniperus phoenicea and Evaluation of its Antibacterial Activity. Int. J. Agric. Biol. 2010, 12, 199-204.

70. Roma-Marzio, F.; Najar, B.; Alessandri, J.; Pistelli, L.; Peruzzi, L. Taxonomy of prickly juniper (Juniperus oxycedrus group): A phytochemical-morphometric combined approach at the contact zone of two cryptospecies. Phytochemistry 2017, 141, 48-60. [CrossRef] [PubMed]

71. Semerdjieva, I.; Zheljazkov, V.D.; Radoukova, T.; Radanović, D.; Marković, T.; Dincheva, I.; Stoyanova, A.; Astatkie, T.; Kačániová, M. Essential oil yield, composition, bioactivity and leaf morphology of Juniperus oxycedrus L. from Bulgaria and Serbia. Biochem. Syst. Ecol. 2019, 84, 55-63. [CrossRef]

72. Politeo, O.; Carev, I.; Bektańević, M. Medicinal plant Mentha pulegium L.—Chemical profile and biological activity of its essential oil. In Proceedings of the International Symposium on Essential Oils (ISEO2018), Niš, Serbia, 13-16 September 2018; 2018; Volume 16, pp. 28-92.

73. De Sousa, D.P.; Nóbrega, F.F.F.; de Lima, M.R.V.; de Almeida, R.N. Pharmacological Activity of (R)-(+)-Pulegone, a Chemical Constituent of Essential Oils. Z. Naturforsch. C 2011, 66, 353-359. [CrossRef]

74. Marín, I.; Sayas-Barberá, E.; Viuda-Martos, M.; Navarro, C.; Sendra, E. Chemical Composition, Antioxidant and Antimicrobial Activity of Essential Oils from Organic Fennel, Parsley, and Lavender from Spain. Foods 2016, 5, 18. [CrossRef] [PubMed]

75. Afsharypuor, S.; Azarbayejany, N. Chemical constituents of the flower essential oil of Lavandula officinalis Chaix. from Isfahan (Iran). Iran. J. Pharm. Sci. 2006, 2, 169-172. 
76. Ferreira, L.E.; Benincasa, B.I.; Fachin, A.L.; Contini, S.H.T.; França, S.C.; Chagas, A.C.S.; Beleboni, R.O. Essential oils of Citrus aurantifolia, Anthemis nobile and Lavandula officinalis: In vitro anthelmintic activities against Haemonchus contortus. Parasites Vectors 2018, 11, 269. [CrossRef] [PubMed]

77. Hassanpouraghdam, M.B.; Hassani, A.; Vojodi, L.; Asl, B.H.; Rostami, A. Essential oil constituents of Lavandula officinalis Chaix. from Northwest Iran. Chemija 2011, 22, 167-171.

78. Pereira, I.; Severino, P.; Santos, A.C.; Silva, A.M.; Souto, E.B. Linalool bioactive properties and potential applicability in drug delivery systems. Colloids Surf. B Biointerfaces 2018, 171, 566-578. [CrossRef] [PubMed]

79. El-Massry, K.F.; El-Ghorab, A.H.; Farouk, A. Antioxidant activity and volatile components of Egyptian Artemisia judaica L. Food Chem. 2002, 79, 331-336. [CrossRef]

80. Aissi, O.; Boussaid, M.; Messaoud, C. Essential oil composition in natural populations of Pistacia lentiscus L. from Tunisia: Effect of ecological factors and incidence on antioxidant and antiacetylcholinesterase activities. Ind. Crops Prod. 2016, 91, 56-65. [CrossRef]

81. Zheljazkov, V.D.; Kacaniova, M.; Dincheva, I.; Radoukova, T.; Semerdjieva, I.B.; Astatkie, T.; Schlegel, V. Essential oil composition, antioxidant and antimicrobial activity of the galbuli of six juniper species. Ind. Crops Prod. 2018, 124, 449-458. [CrossRef]

82. Mimica-Dukić, N.; Božin, B.; Soković, M.; Mihajlović, B.; Matavulj, M. Antimicrobial and Antioxidant Activities of Three Mentha Species Essential Oils. Planta Med. 2003, 69, 413-419.

83. Yadegarinia, D.; Gachkar, L.; Rezaei, M.B.; Taghizadeh, M.; Astaneh, S.A.; Rasooli, I. Biochemical activities of Iranian Mentha piperita L. and Myrtus communis L. essential oils. Phytochemistry 2006, 67, 1249-1255. [CrossRef]

84. Ruberto, G.; Baratta, M.T. Antioxidant activity of selected essential oil components in two lipid model systems. Food Chem. 2000, 69, 167-174. [CrossRef]

85. Vardar-Ünlü, G.; Candan, F.; Sökmen, A.; Daferera, D.; Polissiou, M.; Sökmen, M.; Dönmez, E.; Tepe, B. Antimicrobial and Antioxidant Activity of the Essential Oil and Methanol Extracts of Thymus pectinatus Fisch. et Mey. Var pectinatus(Lamiaceae). J. Agric. Food Chem. 2003, 51, 63-67.

86. Peschel, W.; Sánchez-Rabaneda, F.; Diekmann, W.; Plescher, A.; Gartzía, I.; Jiménez, D.; Lamuela-Raventós, R.; Buxaderas, S.; Codina, C. An industrial approach in the search of natural antioxidants from vegetable and fruit wastes. Food Chem. 2006, 97, 137-150. [CrossRef]

87. Dighe, S.N.; Deora, G.S.; De la Mora, E.; Nachon, F.; Chan, S.; Parat, M.-O.; Brazzolotto, X.; Ross, B.P. Discovery and Structure-Activity Relationships of a Highly Selective Butyrylcholinesterase Inhibitor by Structure-Based Virtual Screening. J. Med. Chem. 2016, 59, 7683-7689. [CrossRef]

88. Benabdallah, A.; Boumendjel, M.; Aissi, O.; Rahmoune, C.; Boussaid, M.; Messaoud, C. Chemical composition, antioxidant activity and acetylcholinesterase inhibitory of wild Mentha species from northeastern Algeria. S. Afr J. Bot. 2018, 116, 131-139. [CrossRef]

89. Miyazawa, M.; Watanabe, H.; Umemoto, K.; Kameoka, H. Inhibition of Acetylcholinesterase Activity by Essential Oils of Mentha Species. J. Agric. Food Chem. 1998, 46, 3431-3434. [CrossRef]

90. Öztürk, M. Anticholinesterase and antioxidant activities of Savoury (Satureja thymbra L.) with identified major terpenes of the essential oil. Food Chem. 2012, 134, 48-54. [CrossRef]

91. Aazza, S.; Lyoussi, B.; Miguel, M.G. Antioxidant and Antiacetylcholinesterase Activities of Some Commercial Essential Oils and Their Major Compounds. Molecules 2011, 16, 7672-7690. [CrossRef]

92. Ballard, C.; Greig, N.; Guillozet-Bongaarts, A.; Enz, A.; Darvesh, S. Cholinesterases: Roles in the Brain During Health and Disease. Curr. Alzheimer Res. 2005, 2, 307-318. [CrossRef]

93. Savelev, S.; Okello, E.; Perry, N.S.L.; Wilkins, R.M.; Perry, E.K. Synergistic and antagonistic interactions of anticholinesterase terpenoids in Salvia lavandulaefolia essential oil. Pharmacol. Biochem. Behav. 2003, 75, 661-668. [CrossRef]

94. Baurin, N.; Arnoult, E.; Scior, T.; Do, Q.; Bernard, P. Preliminary screening of some tropical plants for anti-tyrosinase activity. J. Ethnopharmacol. 2002, 82, 155-158. [CrossRef]

95. Murray, C.; D’Intino, Y.; MacCormick, R.; Nassar, B.; Walsh, N. Melanosis in Association With Metastatic Malignant Melanoma. Am. J. Dermatopathol. 1999, 21, 28-30. [CrossRef] [PubMed]

96. Fiocco, D.; Fiorentino, D.; Frabboni, L.; Benvenuti, S.; Orlandini, G.; Pellati, F.; Gallone, A. Lavender and peppermint essential oils as effective mushroom tyrosinase inhibitors: A basic study. Flavour Fragr. J. 2011, 26, 441-446. [CrossRef] 
97. Peng, H.-Y.; Lai, C.-C.; Lin, C.-C.; Chou, S.-T. Effect of Vetiveria zizanioides Essential Oil on Melanogenesis in Melanoma Cells: Downregulation of Tyrosinase Expression and Suppression of Oxidative Stress. Sci. World J. 2014, 2014, 1-9.

98. Aumeeruddy-Elalfi, Z.; Gurib-Fakim, A.; Mahomoodally, M.F. Kinetic studies of tyrosinase inhibitory activity of 19 essential oils extracted from endemic and exotic medicinal plants. S. Afr. J. Bot. 2016, 103, 89-94. [CrossRef]

99. Huang, H.-C.; Ho, Y.-C.; Lim, J.-M.; Chang, T.-Y.; Ho, C.-L.; Chang, T.-M. Investigation of the Anti-Melanogenic and Antioxidant Characteristics of Eucalyptus camaldulensis Flower Essential Oil and Determination of Its Chemical Composition. Int. J. Mol. Sci. 2015, 16, 10470-10490. [CrossRef]

100. Hosseinzadeh, L.; Shokoohinia, Y.; Arab, M.; Allahyari, E.; Mojarrab, M. Cytotoxic and Apoptogenic Sesquiterpenoids from the Petroleum Ether Extract of Artemisia aucheri Aerial Parts. Iran. J. Pharm. Res. 2019, 18, 391-399.

101. Bardaweel, S.K.; Bakchiche, B.; ALSalamat, H.A.; Rezzoug, M.; Gherib, A.; Flamini, G. Chemical composition, antioxidant, antimicrobial and Antiproliferative activities of essential oil of Mentha spicata L. (Lamiaceae) from Algerian Saharan atlas. BMC Complement. Altern. Med. 2018, 18, 201. [CrossRef]

102. Zardi-Bergaoui, A.; Jelizi, S.; Flamini, G.; Ascrizzi, R.; Ben Jannet, H. Comparative study of the chemical composition and bioactivities of essential oils of fresh and dry seeds from Myoporum insulare $\mathrm{R}$. Br. Ind. Crops Prod. 2018, 111, 232-237. [CrossRef]

103. Mosbah, H.; Louati, H.; Boujbiha, M.A.; Chahdoura, H.; Snoussi, M.; Flamini, G.; Ascrizzi, R.; Bouslema, A.; Achour, L.; Selmi, B. Phytochemical characterization, antioxidant, antimicrobial and pharmacological activities of Feijoa sellowiana leaves growing in Tunisia. Ind. Crops Prod. 2018, 112, 521-531. [CrossRef]

104. Davies, N.W. Gas chromatographic retention indices of monoterpenes and sesquiterpenes on Methyl Silicon and Carbowax 20M phases. J. Chromatogr. A 1990, 503, 1-24. [CrossRef]

105. Adams, R.P. Identification of Essential Oil Components by Gas Chromatography/Mass Spectroscopy; Allured Pub. Corp.: Carol Stream, IL, USA, 2007.

106. Joulain, D.; König, W. The Atlas of Spectral Data of Sesquiterpene Hydrocarbons; E.B. Verlag: Hamburg, Germany, 1998; ISBN 3-930826-48-8.

107. Sánchez-Moreno, C.; Larrauri, J.A.; Saura-Calixto, F. A procedure to measure the antiradical efficiency of polyphenols. J. Sci. Food Agric. 1998, 76, 270-276. [CrossRef]

108. Oyaizu, M. Studies on products of browning reaction. Antioxidative activities of products of browning reaction prepared from glucosamine. Jpn. J. Nutr. Diet. 1986, 44, 307-315. [CrossRef]

109. Re, R.; Pellegrini, N.; Proteggente, A.; Pannala, A.; Yang, M.; Rice-Evans, C. Antioxidant activity applying an improved ABTS radical cation decolorization assay. Free Radic. Biol. Med. 1999, 26, 1231-1237. [CrossRef]

110. Ellman, G.L.; Courtney, K.D.; Andres, V.; Featherstone, R.M. A new and rapid colorimetric determination of acetylcholinesterase activity. Biochem. Pharmacol. 1961, 7, 88-95. [CrossRef]

111. Liu, J.; Wu, F.; Chen, L.; Zhao, L.; Zhao, Z.; Wang, M.; Lei, S. Biological evaluation of coumarin derivatives as mushroom tyrosinase inhibitors. Food Chem. 2012, 135, 2872-2878. [CrossRef]

112. Bouziane, A.; Bakchiche, B.; Dias, M.; Barros, L.; Ferreira, I.; AlSalamat, H.; Bardaweel, S. Phenolic Compounds and Bioactivity of Cytisus villosus Pourr. Molecules 2018, 23, 1994. [CrossRef]

Sample Availability: Samples are available from the authors.

(C) 2020 by the authors. Licensee MDPI, Basel, Switzerland. This article is an open access article distributed under the terms and conditions of the Creative Commons Attribution (CC BY) license (http://creativecommons.org/licenses/by/4.0/). 